\title{
A functional map of genomic HIF1a-DNA complexes in the eye lens revealed through multiomics analysis
}

\author{
Joshua Disatham', Lisa Brennan', Daniel Chauss², Jason Kantorow³ ${ }^{3}$ Behdad Afzali² and Marc Kantorow ${ }^{\text {* }}$
}

\begin{abstract}
Background: During eye lens development the embryonic vasculature regresses leaving the lens without a direct oxygen source. Both embryonically and throughout adult life, the lens contains a decreasing oxygen gradient from the surface to the core that parallels the natural differentiation of immature surface epithelial cells into mature core transparent fiber cells. These properties of the lens suggest a potential role for hypoxia and the master regulator of the hypoxic response, hypoxia-inducible transcription factor 1 (HIF1), in the regulation of genes required for lens fiber cell differentiation, structure and transparency. Here, we employed a multiomics approach combining CUT\&RUN, RNA-seq and ATACseq analysis to establish the genomic complement of lens HIF1a binding sites, genes activated or repressed by HIF1a and the chromatin states of HIF1a-regulated genes.

Results: CUT\&RUN analysis revealed 8375 HIF1a-DNA binding complexes in the chick lens genome. One thousand one hundred ninety HIF1a-DNA binding complexes were significantly clustered within chromatin accessible regions ( $X^{2}$ test $p<1 \times 10^{-55}$ ) identified by ATACseq. Formation of the identified HIF1a-DNA complexes paralleled the activation or repression of 526 genes, 116 of which contained HIF1a binding sites within 10kB of the transcription start sites. Some of the identified HIF1a genes have previously established lens functions while others have novel functions never before examined in the lens. GO and pathway analysis of these genes implicate HIF1a in the control of a wide-variety of cellular pathways potentially critical for lens fiber cell formation, structure and function including glycolysis, cell cycle regulation, chromatin remodeling, Notch and Wnt signaling, differentiation, development, and transparency.

Conclusions: These data establish the first functional map of genomic HIF1a-DNA complexes in the eye lens. They identify HIF1a as an important regulator of a wide-variety of genes previously shown to be critical for lens formation and function and they reveal a requirement for HIF1a in the regulation of a wide-variety of genes not yet examined for lens function. They support a requirement for HIF1a in lens fiber cell formation, structure and function and they provide a basis for understanding the potential roles and requirements for HIF1a in the development, structure and function of more complex tissues.
\end{abstract}

Keywords: HIF1a, Hypoxia, CUT\&RUN, ATAC-seq, RNA-seq, Gene regulation, DNA binding, Chromatin, Transcriptional regulation

\footnotetext{
* Correspondence: mkantoro@health.fau.edu

${ }^{1}$ Charles E. Schmidt College of Medicine, Florida Atlantic University, 777

Glades Rd., Boca Raton, FL 33431, USA

Full list of author information is available at the end of the article
}

\section{$\triangle B M C$}

(c) The Author(s). 2021 Open Access This article is licensed under a Creative Commons Attribution 4.0 International License, which permits use, sharing, adaptation, distribution and reproduction in any medium or format, as long as you give appropriate credit to the original author(s) and the source, provide a link to the Creative Commons licence, and indicate if changes were made. The images or other third party material in this article are included in the article's Creative Commons licence, unless indicated otherwise in a credit line to the material. If material is not included in the article's Creative Commons licence and your intended use is not permitted by statutory regulation or exceeds the permitted use, you will need to obtain permission directly from the copyright holder. To view a copy of this licence, visit http://creativecommons.org/licenses/by/4.0/ The Creative Commons Public Domain Dedication waiver (http://creativecommons.org/publicdomain/zero/1.0/) applies to the data made available in this article, unless otherwise stated in a credit line to the data. 


\section{Background}

The mature eye lens is composed of an anterior layer of organelle-containing epithelial cells that during development and throughout adult life continuously differentiate to form a core of transparent organelle-free lens fiber cells [1]. The process of mammalian eye lens formation occurs during major changes in lens oxygen availability. In early development, the embryonic lens receives oxygen from a network of capillaries comprised of the tunica vasculosa lentis and the anterior pupillary membrane [2]. However, as newly forming secondary lens fiber cells are just beginning to initiate the elimination of organelles and the expression of key proteins required for mature lens fiber cell formation and function, this capillary network has been eliminated leaving the lens in a hypoxic environment [2] with the vitreous and aqueous humors as the only source of oxygen for the lens [3-6]. Low levels of oxygen contained in the aqueous humor combined with consumption of oxygen by the mitochondria containing lens epithelial cells at the surface of the lens contribute to a hypoxic environment below the lens surface where lens epithelial cells differentiate into lens fiber cells $[4,5]$ and in the transitional zone of the lens where lens organelle degradation takes place and lens fiber cell differentiation is initiated. Consistently, studies on interior lens oxygen levels reveal a 20-fold decrease in oxygen levels from the epithelial cellcontaining surface of the lens to the differentiating lens fiber cells [5]. This oxygen gradient parallels a widevariety of hallmark events that characterize the formation of mature lens fiber cells including the elimination of cellular organelles and the expression of critical genes required for lens fiber cell transparency and function.

Consistent with a requirement for hypoxia in the elimination of organelles to form mature lens fiber cells, hypoxia has been shown to be required for induction of the mitophagy gene BNIP3L in lens fiber cells that directs the elimination of non-nuclear organelles during lens fiber cell formation $[7,8]$ making BNIP3L an ideal control for the present study. BNIP3L is a BH3-only member of the Bcl-2 family [9], whose expression is induced by hypoxia in other cell types [10]. BNIP3L is upregulated during reticulocyte differentiation [11], extensive studies on BNIP3L show that it is required for elimination of mitochondria during reticulocyte differentiation [12-15] and, consistently, fully mature erythrocytes in BNIP3L knockout mice retain mitochondria resulting in dysfunctional erythropoiesis and anemia $[13,16]$.

In addition to demonstrating a role for hypoxia in the activation of BNIP3L gene expression in newly forming secondary lens fiber cells, expression of BNIP3L was also shown to be regulated through the hypoxia-dependent binding of the transcription factor hypoxia-inducible transcription factor 1 (HIF1) to the BNIP3L promoter
[8]. Consistent with the possibility that HIF1 $\alpha$ regulates other genes needed for lens fiber cell differentiation, lenses lacking HIF1 $\alpha$ degenerate shortly after birth and their analysis reveals extensive vacuolization and fiber cell dysmorphology consistent with aberrant lens fiber cell differentiation [17].

Hypoxia regulates all three members of the hypoxia inducible factor (HIF) family of transcription including HIF1, HIF2 and HIF3 [18-20]. In most cells, the master regulator of the hypoxic response is HIF1 [18-22]. HIF1 is the predominant HIF expressed in the lens being expressed at 120-fold higher levels than HIF2 while HIF3 is not detected in the lens [23]. Although primarily investigated as an essential regulator of vascularization [24], emerging evidence suggests that HIF1 plays key roles in the regulation of a wide variety of cellular processes required for the development, homeostasis and/or disease states of a wide variety of tissues in addition to the eye lens [25-32].

HIF1 is a heterodimer made up of two subunits, HIF1 $\beta / A R N T$ and HIF1 $\alpha$. The HIF1 $\beta / A R N T$ subunit is expressed constitutively but the protein level of HIF $1 \alpha$ is tightly regulated in response to environmental oxygen levels. Under normoxic (21\% oxygen) conditions, HIF1 $\alpha$ is regulated through post-translational hydroxylation of prolines in its oxygen dependent domain (ODD) by members of the 2-oxoglutarate-dependent dioxygenase superfamily of prolyl hydroxylases (PHD1, PHD2 and PHD3) $[18,19]$. Proline hydroxylation promotes interaction with the von Hippel-Lindau tumour suppressor protein, targeting HIF1 $\alpha$ for proteasomal degradation $[18,19]$. Additional hydroxylation of an asparaginyl moiety in the C-terminus inhibits binding of HIF1 $\alpha$ to its co-factors, p300 and CREB binding protein (CBP), directly inhibiting its transcriptional activity [18, 19, 21]. Under hypoxic conditions, oxygen-dependent PHDs are inactivated, allowing HIF $1 \alpha$ to bind to nuclear pores and translocate to the nucleus where it dimerizes with HIF1 $\beta$ /ARNT and recruits CBP and p300 to regulate transcription [18, 19, 21, 33].

To date, the range and spectrum of genes controlled by HIF $1 \alpha$, particularly in primary cells, has not been fully elucidated. In the present report we identified those lens genes regulated by HIF1 $\alpha$ by employing Cleavage Under Targets and Release Under Nuclease (CUT\&RUN) [34, 35] to map the genome-wide complement of HIF1 $\alpha$-DNA binding complexes present in a well-characterized primary embryonic chick lens cell model system. This model system has been previously used to successfully investigate a multiple lens properties and functions including lens cell differentiation, gene expression, autophagy/mitophagy [36, 37], PI3K signaling [38], TGFB signaling [39, 40] and gap junction expression and function [41]. Using CUT\&RUN, we mapped 
the positions of the identified HIF1 $\alpha$-DNA binding complexes relative to transcription start sites of nearest neighbor genes. We then employed RNA-seq to correlate the presence of HIF1-DNA binding complexes with changes in gene expression occurring upon HIF1 $\alpha-$ activation. Finally, we examined the relationship between HIF1 $\alpha$-DNA binding, gene activation or repression and chromatin accessibility through analysis of Assay for Transposase-Accessible Chromatin sequencing (ATACseq) data [42, 43]. For these studies, we chose CUT\&RUN over Chromatin Immunoprecipitation sequencing (ChIP-seq) analysis since only a few thousand cells are required for technical success, whereas ChIPseq requires millions of cells for the same output level [34]. Moreover, CUT\&RUN assesses DNA-binding in the native state and does not require DNA-protein cross-linking, which can introduce artefacts [34].

CUT\&RUN analysis using a HIF $1 \alpha$-specific antibody identified over 8000 HIF1 $\alpha$-DNA specific complexes in primary lens cells following HIF $1 \alpha$ activation. As validation, motif analysis of the identified binding sites confirmed enrichment of the HIF $1 \alpha$ consensus sequence. One thousand one hundred ninety of the identified binding complexes were contained in chromatin accessible regions identified by ATAC-seq [43]. Activation of HIF1 $\alpha$ was required for activation or repression of 526 genes identified by RNA sequencing. One hundred sixteen of these genes contained HIF1 $\alpha$-DNA binding complexes within $10 \mathrm{kB}$ of the transcription start sites (TSS's) of coding genes.

These data establish the first functional map of genomic HIF $1 \alpha$-DNA complexes in the eye lens. They identify HIF $1 \alpha$ as an important regulator of a wide-variety of genes previously shown to be critical for lens formation and function and they reveal a requirement for HIF $1 \alpha$ in the regulation of a wide-variety of multiple novel genes. Collectively, the results support a requirement for HIF1 $\alpha$ in lens development, structure and function and they provide a basis for understanding the potential roles and requirements for HIF1 $\alpha$ in the development, structure and function of more complex tissues.

\section{Results}

\section{CUT\&RUN identifies 8375 HIF1a-DNA binding complexes in the lens genome}

Multiple lines of evidence suggest an essential role for HIF1 $\alpha$ in regulating gene expression pathways leading to mature lens cell structure and function. The lens resides in a hypoxic environment [4-6, 44], lens deletion of HIF1 $\alpha$ disrupts lens cell structure and development [17] and hypoxia and HIF $1 \alpha$ are required for the elimination of non-nuclear organelles during mature lens cell formation through activation of the BNIP3L gene [8]. Based on these data, we hypothesized that HIF1 $\alpha$ could regulate a wide-variety of genes involved in multiple genetic pathways important for mature lens cell structure and function. To establish the range and spectrum of lens genes regulated by HIF $1 \alpha$, we first sought to establish the genomic-level occupancy of HIF1 $\alpha$-DNA binding complexes in primary lens cells upon HIF1 $\alpha$ activation using Cleavage Under Targets \& Release Using Nuclease (CUT\&RUN) (Fig. 1A-B). HIF1 $\alpha$ was activated in primary embryonic chick (Gallus gallus) lens cells by exposure to $1 \mathrm{mM}$ dimethyloxalylglycine (DMOG) for 4 h. This 4-h DMOG treatment was selected based on previous embryonic whole chick lens studies in Gallus gallus [8] showing this time of exposure resulted in robust binding of HIF $1 \alpha$ to its cognate site of the BNIP3L gene promoter detected by ChIP-qPCR and robustly activated BNIP3L transcription detected by RT-PCR [8]. BNIP3L is an established HIF1 $\alpha$ target in multiple celltypes $[8,45,46]$. In this study, exposure of primary lens cells to $1 \mathrm{mM}$ DMOG for $4 \mathrm{~h}$ also resulted in a greater than 2-fold increase in BNIP3L mRNA (Fig. 1C-D, Supplementary Figure S1).

Biological duplicates of primary chicken lens cell preparations were treated with $1 \mathrm{mM}$ DMOG for $4 \mathrm{~h}$ to activate HIF1 $\alpha$ followed by in situ HIF1 $\alpha$ CUT\&RUN [34, 35]. Following Illumina sequencing, small chromatin fragments were mapped across the Galgal6 genome and interrogated for enrichment relative to an IgG isotype control CUT\&RUN. There were 8375 HIF1 $\alpha$-DNA binding complexes across the Galgal6 genome with high resolution and specificity (Table S1). These exhibited specific binding within narrow regions of chromatin. A heatmap of all identified HIF1 $\alpha$-DNA binding complexes is shown in Fig. 2A. The data reveal the presence of a highly enriched HIF1 $\alpha$ signal relative to the control IgG signal at genomic regions containing identified HIF1 $\alpha$ DNA binding complexes. To validate the binding identified by CUT\&RUN, we analyzed nucleotide patterns in DNA sequences underlying genomic regions bound by HIF1 $\alpha$ using de novo motif discovery to determine enrichment of transcription factor footprints at these loci. The most significant motif identified was the canonical HIF1 $\alpha$ motif (5'-ACGTG-3'; $\mathrm{E}<3.6 \times 10^{-111}$, Fig. 2B), confirming the presence of the HIF1 $\alpha$ binding sequence in DNA regions identified to be bound to HIF1 $\alpha$ by CUT\&RUN. The second most significant motif identified was 5'-KCTGTR-3'; E $<8.3 \times 10^{-98}$ (Supplementary Figure S2) which is not known to bind HIF1 $\alpha$ or other transcription factors.

The majority of identified HIF1 $\alpha$-DNA binding complexes were located within $100 \mathrm{kbp}$ of the nearest gene transcription start site (Fig. 2C), indicating a potential role in transcriptional regulation. Consistent with our findings, a previous study performed CHIPseq to map HIF1 $\alpha$ binding sites in a breast cancer cell line model 

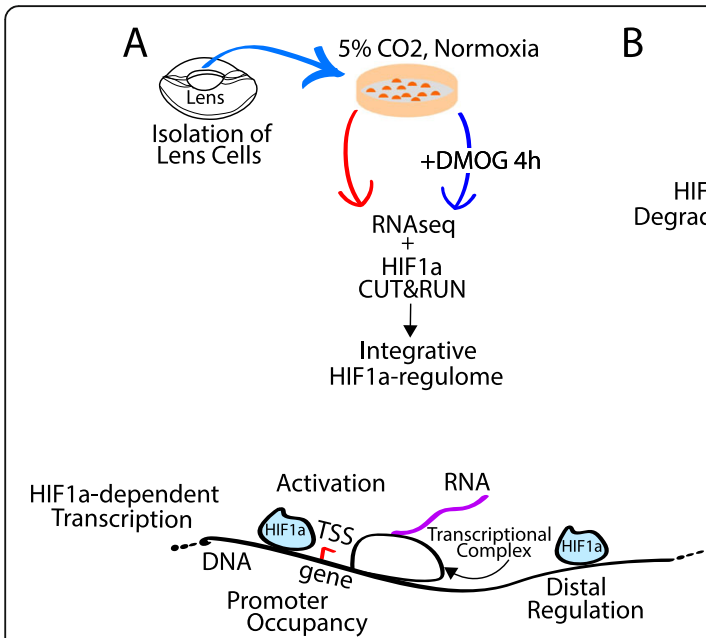
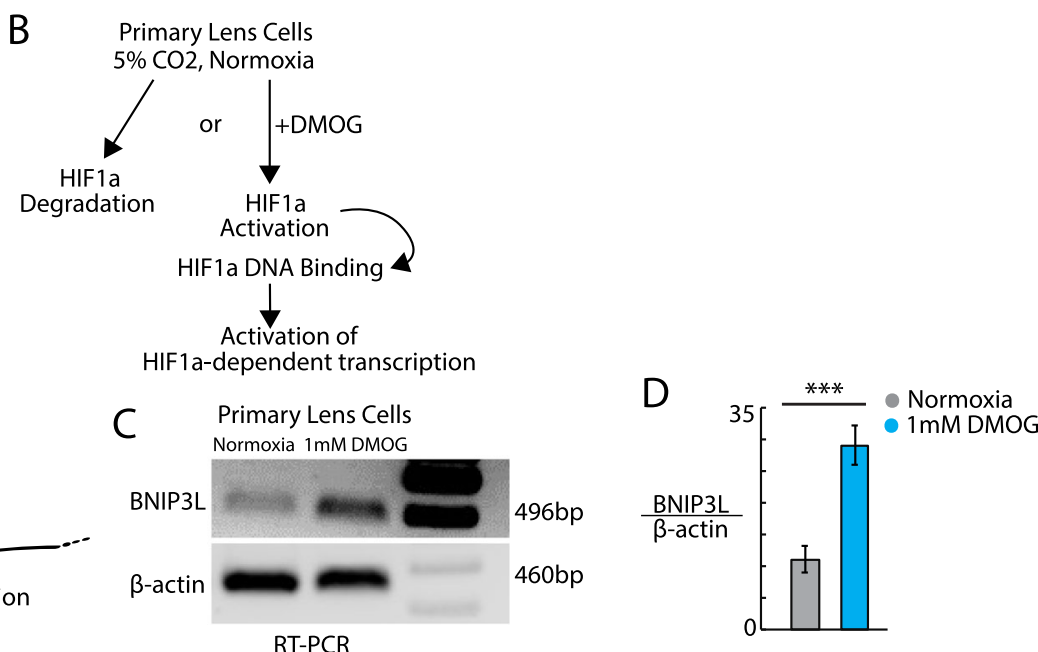

Fig. 1 Multiomic identification of functional HIF1a DNA binding targets in the lens genome. A Duplicate pools of 500,000 primary chick lens cells were cultured with or without the HIF1a activator DMOG (1 mM) for $4 \mathrm{~h}$. Samples were analyzed by CUT\&RUN and RNA-seq analysis to identify genome-wide HIF1a-DNA binding complexes and corresponding HIF1a-dependent gene expression changes. Results were compared with ATACseq data [43] to identify the chromatin accessibility of identified HIF1a-DNA binding complexes. Integrated bioinformatics analysis was used to identify the pathways and functions specific for identified HIF1a-targets. B HIF1a is rapidly degraded under normoxic conditions but the presence of DMOG, inhibits prolyl hydroxylase resulting in HIF1a stabilization, DNA binding and transcriptional modulation in lens cells. C-D RTPCR showing increased levels of the BNIP3L control transcript relative to $\beta$-actin in lens cells incubated in the presence of $1 \mathrm{mM}$ DMOG for 4 h. ${ }^{*} p<0.05$ t-test $n=3$

[47]. They found that a large majority of HIF $\alpha$ binding sites were within $10 \mathrm{~kb}$ of the nearest transcription start site. Another study also used CHIPseq to map HIF $1 \alpha$ binding sites in HKC-8, RCC4, and HepG2 cells [48]. They found that a majority of HIF $1 \alpha$ binding sites were within $5 \mathrm{~kb}$ of the nearest transcription start site. CUT\&RUN is able to identify distal transcription factor binding sites with greater accuracy and resolution compared to CHIPseq [34] and so our results likely indicate the identification of a large number of distal HIF $1 \alpha$ binding sites that CHIPseq did not identify.

To determine whether the observed distribution could have occurred by chance, we compared binding patterns of HIF1 $\alpha$-DNA complexes identified by CUT\&RUN on DMOG-treated primary lens cells to a computergenerated random distribution of HIF $1 \alpha-D N A$ binding complexes across the genome. We found that the 8375 HIF1 $\alpha$ DNA binding sites clustered closer to transcription start sites of genes compared to the computergenerated random distribution model of HIF $1 \alpha$ DNA binding ( $\mathrm{X}^{2}$ test $p<2 \times 10^{-16}$, Fig. 2D). Specifically, HIF1 $\alpha$-DNA binding complexes were clustered more within $10 \mathrm{~kb}$ of transcription start sites and clustered less at ranges greater than $10 \mathrm{~kb}$ compared to the computergenerated model of randomly distributed HIF $1 \alpha$-DNA binding complexes. One thousand three hundred fiftynine HIF $1 \alpha-D N A$ binding complexes (16.2\%) were mapped within $3 \mathrm{~kb}$ of transcription start sites, 3708 HIF1 $\alpha$-DNA binding complexes (44.3\%) were found to be within gene bodies, and 3308 HIF1 $\alpha$-DNA binding complexes (39.5\%) were mapped to intergenic regions greater than $3 \mathrm{~kb}$ away from transcription start sites of genes (Fig. 2E). HIF1 $\alpha$-DNA binding complexes were also found to be positively associated with proximal promoter regions $(+/-3 \mathrm{kbp}$ region around transcription start sites) and negatively associated with gene body regions relative to the computer-generated random distribution of HIF1 $\alpha$-DNA binding complexes $\left(p<1 \times 10^{-11}\right.$, Fig. 2F)). Additionally, there were 1763 gene transcription start sites that were nearest neighbors to at least two HIF $1 \alpha$ binding sites. Three hundred ten gene transcription start sites have at least one HIF $1 \alpha$ binding site $<3 \mathrm{~kb}$ AND at least one HIF1 $\alpha$ binding site $>3 \mathrm{~kb}$ away.

Active gene regulatory regions often cluster in regions of accessible chromatin comprised of low nucleosome density [49-51]. Notably, our previous study identified the canonical HIF1 $\alpha$ motif as one of the top enriched motifs contained within open chromatin regions identified in the embryonic chick lens genome by ATAC-seq [43]. We therefore compared our HIF1 $\alpha$ DNA binding complexes identified by CUT\&RUN to these previously identified open chromatin regions. The analysis revealed 1190 HIF1 $\alpha$-DNA binding complexes (14.2\%) identified by CUT\&RUN that were also contained within genomic regions that exist as open chromatin regions in embryonic chick lens genome (Table S1). HIF1 $\alpha$-DNA binding complexes were also found to be positively associated with open chromatin regions and negatively associated 


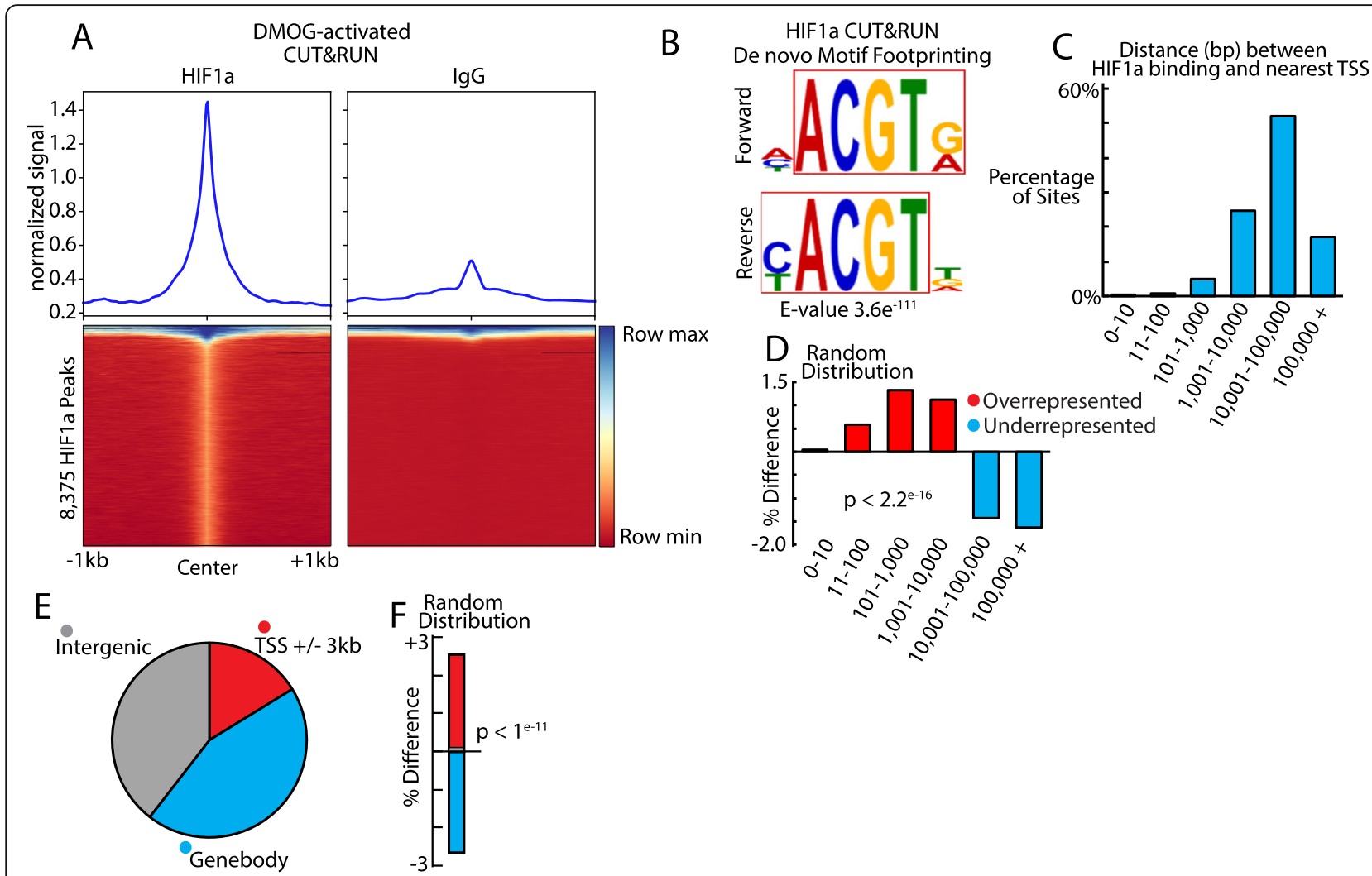

Fig. 2 The spectrum and specificity of HIF1a-DNA binding complexes of the lens genome. A Heatmap of HIF1a binding signal compared to lgG signal at all genomic regions containing HIF1a-DNA binding complexes identified by CUT\&RUN. B De novo motif analysis of HIF1a-DNA binding complexes identified by CUT\&RUN. The canonical HIF1a consensus sequence was the most significantly enriched motif (E-value $\left.3.6 \times 10^{-111}\right)$. C Percent of the 8375 HIF1a-DNA binding complexes identified by CUT\&RUN that were found within the indicated distances from the nearest gene transcription start site. D Relative percentage difference between the distribution of HIF1a-DNA binding complexes identified by CUT\&RUN compared to computer generated HIF1a-DNA binding complexes randomly distributed across the genome and sorted by distance to the nearest gene transcription start site. $\left(X^{2}\right.$-test, $\left.p<2.2 \times 10^{-16}\right)$. E Percent of the 8375 HIF1a-DNA binding complexes identified by CUT\&RUN that were found within proximal promoter regions (+/- $3 \mathrm{kbp}$ of gene transcription start sites), genebodies, or intergenic regions. F Relative percentage difference between the distribution of HIF1a-DNA binding complexes identified by CUT\&RUN compared to computer generated HIF1a-DNA binding complexes randomly distributed across the genome and classified as found within proximal promoter regions (+/- $3 \mathrm{kbp}$ of gene transcription start sites), genebodies, or intergenic regions. $\left(X^{2}\right.$-test, $\left.p<1 \times 10^{-11}\right)$

with closed chromatin regions compared to the computer-generated random distribution of HIF1 $\alpha$-DNA binding complexes $\left(x^{2}\right.$ test $\left.p<1 \times 10^{-55}\right)$. We also sought to determine if the distance between the HIF1 $\alpha$ DNA binding complex and the transcription start sites of genes was significantly associated with binding to open chromatin regions. We categorized the CUT\&RUN-identified HIF1 $\alpha$-DNA binding sites by distance from the nearest gene transcription start site $(0-3$ $\mathrm{kb}, 3-10 \mathrm{~kb}, 10-100 \mathrm{~kb},+100 \mathrm{~kb})$ and whether the HIF1 $\alpha$-DNA binding site overlapped an open chromatin region or closed chromatin region. We then repeated this categorization for a computer-generated random distribution of HIF1 $\alpha$-DNA binding sites and compared the differences. This analysis found that HIF1 $\alpha$-DNA binding complexes were positively associated with open chromatin regions and negatively associated with closed chromatin regions compared to what is expected from a computer-generated random distribution of HIF $1 \alpha$ binding sites. This association was consistent even when separating the HIF $1 \alpha$ binding sites by distance from the nearest gene transcription start site (Fig. 3A). These data suggest that HIF1 $\alpha$ binding to regions near transcription start sites in the genome is biologically specific.

Such proximity to promoters and enrichment of binding within gene bodies and open chromatin regions, indicated with high probability that HIF1 $\alpha$ is likely to be a direct transcriptional regulator of a large proportion of bound genes. Consistently, CUT\&RUN identified the HIF1 $\alpha$-DNA binding complex previously discovered by ChIP-qPCR in the $5^{\prime}$-proximal upstream region of BNIP3L (Fig. 3B) [8] that also overlaps with open chromatin regions previously identified by ATACseq of embryonic chick lenses [43]. Additional visualizations of 


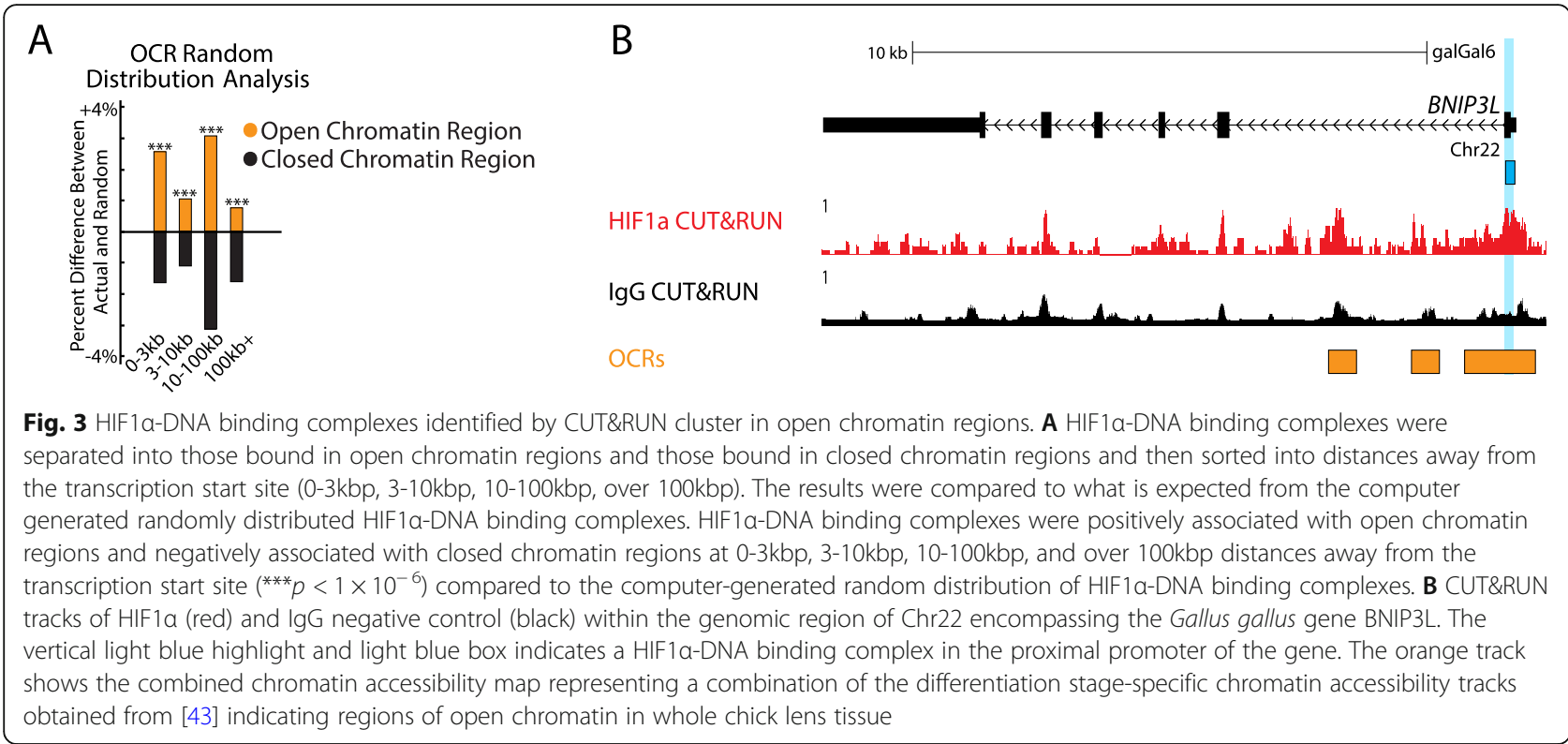

HIF1 $\alpha$ CUT\&RUN signal tracks and open chromatin regions in the Galgal6 genome can be found at the UCSC genome browser link (https://genome.ucsc.edu/s/ jdisatha/CUTRUN_Lens_HIF1A).

\section{HIF1a binding induces expression of numerous genes in lens cells}

To determine the range and spectrum of gene transcriptional events corresponding with HIF1 $\alpha$ DNA binding occupancy in lens cells, we performed RNA-seq on primary lens cells under the same conditions performed for the CUT\&RUN analysis. This activation of HIF $1 \alpha$ by DMOG resulted in upregulation of 219 genes and downregulation of 309 genes $(\log 2 \mathrm{FC}$ at least 0.60 in either direction at $p<0.05$ ) (Fig. 4A, D, Table S2). Genes that are upregulated following treatment with DMOG have significantly lower expression levels in lens cells that were not exposed to DMOG. Genes that are downregulated following treatment with DMOG have significantly higher expression levels in lens cells that were not exposed to DMOG. To determine if there was a direct correlation between HIF1 $\alpha$ binding and changes in gene expression, each HIF1 $\alpha$ DNA-binding locus was mapped to the transcription start site (TSS) of nearest neighbor genes. This analysis revealed that upon HIF1 $\alpha$ activation, $40 \%$ (212 of 528) of differentially expressed genes (DEGs) were bound by HIF $1 \alpha\left(p<0.001 \chi^{2}\right.$ test compared to genes unchanged in DMOG-exposed cells, non-DEG)) (Fig. 4B). We also sought to determine whether this significant association was specifically dependent on gene induction or repression. We did this by separating the differentially expressed genes into upregulated and downregulated genes. This analysis found that upon HIF1 $\alpha$ activation, both $46.1 \%$ (101 of 219) of upregulated genes and $36.2 \%$ (111 of 309) of downregulated genes were bound by HIF $1 \alpha(p<0.001$ and $<0.01$, respectively by $\chi^{2}$ test relative to non-DEG) (Fig. $4 \mathrm{E}, \mathrm{G}$ ). Additionally, genes exhibiting HIF1 $\alpha$-DNA binding had greater magnitude fold changes (abs $(\log 2 \mathrm{FC}), p<1 \times$ $10^{-7}$ Mann-U Whitney test) compared to genes not bound by HIF1 $\alpha$. Taken together, these data indicated a significant role for HIF $1 \alpha$ binding in lens cell gene regulation.

We next sought to determine whether the distance between the HIF1 $\alpha$-DNA binding complex and the TSS of genes was correlated with gene induction or repression in HIF $1 \alpha$-activated primary lens cells. A significantly higher percentage of differentially expressed genes were bound by HIF $1 \alpha$ within $3 \mathrm{~kb}$ (61 of $526(11.6 \%)$, $\mathrm{x}^{2}$ test $\left.p<0.001\right)$, $10 \mathrm{~kb}$ (55 of $526(10.5 \%), \chi^{2}$ test $p<0.001$ ), and $100 \mathrm{kbp}$ (86 of $526(16.3 \%), \chi^{2}$ test $p<0.01$ ) from the transcription start site compared to non-differentially expressed genes (940 of 16,777 (5.6\%), 1191 of 16,777 (7.1\%), 2366 of 16, 777 (14.1\%) respectively) (Fig. 4C). This indicated that proximity of HIF1 $\alpha$ binding to the TSS correlates with activation or repression of gene transcription. Consistently, upregulated genes were significantly enriched in HIF1 $\alpha$ binding within $3 \mathrm{~kb}$ of the TSS compared to both downregulated and non-responsive genes (Fig. 4F, H). Conversely, down-regulated genes were significantly enriched in HIF1 $\alpha$ binding between $3 \mathrm{kbp}-10 \mathrm{kbp}$ away from the TSS relative to non-responsive genes (Fig. 4F, H). Thus, genes induced by HIF1 $\alpha$ were more likely to exhibit proximal HIF1 $\alpha$ binding near the TSS and genes repressed by HIF $1 \alpha$ were more likely to be bound by HIF $1 \alpha$ at a greater distance from the TSS (Fig. 4I). 


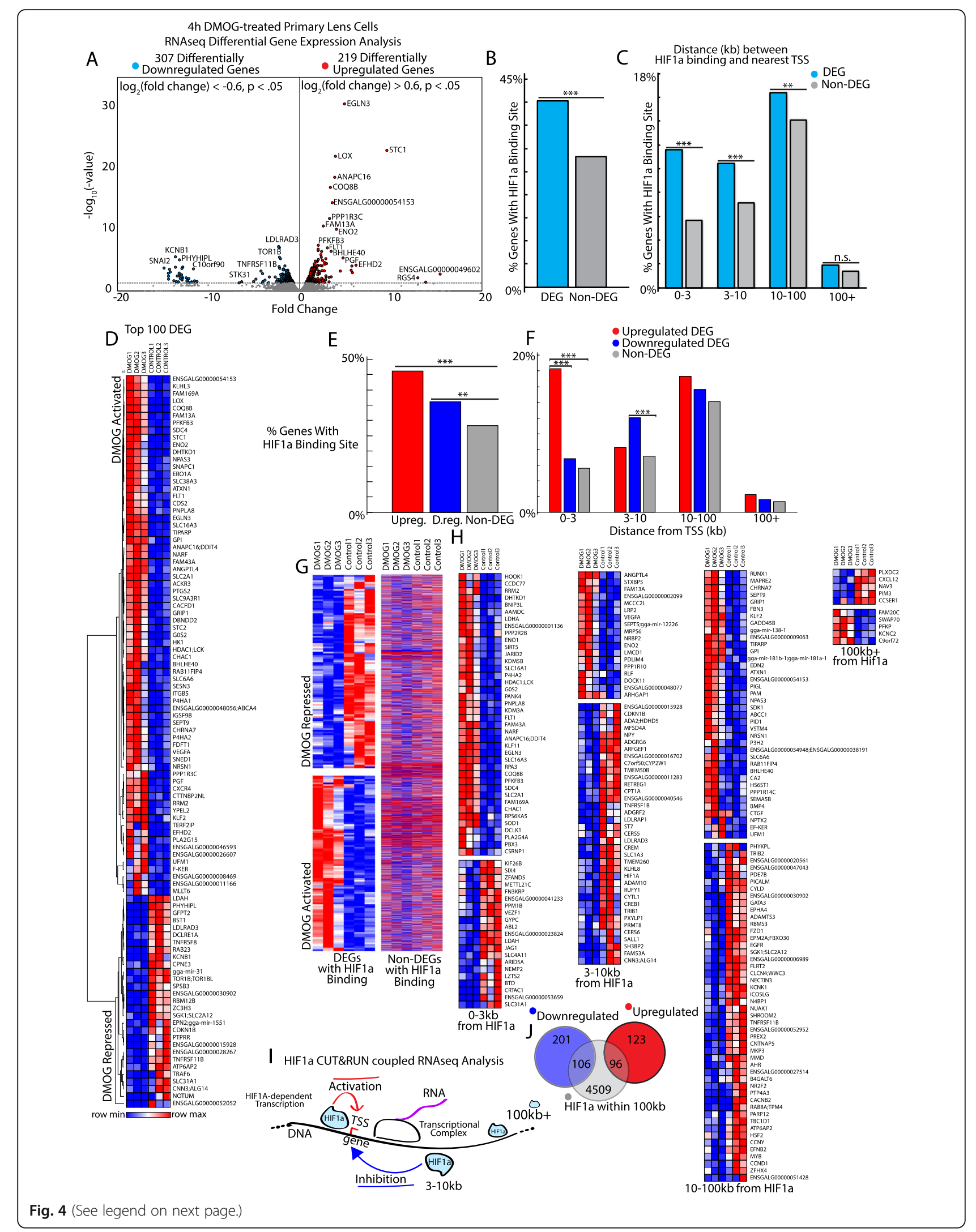


(See figure on previous page.)

Fig. 4 HIFla binds to and regulates the expression of over 200 lens genes: A Differential gene expression analysis by RNA-seq reveals 219 upregulated genes (log2 fold change FPKM $>0.6, p<0.05$ ) and 307 downregulated genes (log2 fold change FPKM $<-0.6, p<0.05$ ) in primary lens cells treated with the HIF1a activator DMOG (1 mM) relative to control untreated cells. B Percent of differentially expressed genes (DEG) ( $\mid \log 2$ fold change FPKM $\mid>0.6, p<0.05)$ and non-differentially expressed genes (NON-DEG) $(p>0.05)$ that have a HIF1a-DNA binding complex. Differentially expressed genes are more significantly associated with HIF1a binding compared to non-differentially expressed genes ( $X^{2}$-test, $\left.{ }^{* * *} p<0.001\right)$. C Same analysis as (B) but separated by distance between the transcription start site (TSS) and the HIF1a-DNA binding complex. $\left(X^{2}\right.$-tests, ${ }^{* * *} p<0.001,{ }^{* *} p<0.01$, ns $\left.p>0.05\right)$. D Heatmap of the top 100 differentially expressed genes sorted by hierarchal clustering. E Percent of upregulated genes, downregulated genes and NON-DEG that have a HIF1a-DNA binding complex. Upregulated and downregulated genes are significantly associated with HIF1a-DNA binding complexes. ( $X^{2}$-test, $\left.{ }^{* * *} p<0.001,{ }^{* *} p<0.01\right)$. F Same analysis as (E) but separated by distance between the transcription start site (TSS) and the HIF1a-DNA binding complex. ( $X^{2}$-test, $\left.{ }^{* * *} p<0.001\right)$. (G) Heatmap of differentially expressed (DEGs) and non-differentially expressed (Non-DEGs) genes with a HIF1a-DNA binding complex (DEGs). H Same as (G) but separated by distance from the transcription start site (0-3kbp, 3-10kbp, 10-100kbp, and over 100kbp). I HIF1a CUT\&RUN coupled to RNA-seq analysis elucidates a significant relationship between HIF1a binding within 3kbp of the TSS and gene upregulation. In contrast, HIF1a binding between 3-10kbp of the TSS is significantly associated with gene downregulation. J Overlap of number of genes that are significantly upregulated or significantly downregulated and genes with HIF1a-DNA binding complexes within 100kbp of the transcription start site

We also compared consensus binding sequences between HIF1 $\alpha$ sites near induced genes versus HIF1 $\alpha$ sites near repressed genes. Using the DREME tool, we did not find a statistically significant difference between the enriched consensus sequences at HIF1 $\alpha$ sites near induced genes versus HIF $1 \alpha$ sites near repressed genes.

Since there was a statistically significant association between altered expression of genes upon HIF1 $\alpha$ activation and HIF1 $\alpha$ binding to proximal regions within $100 \mathrm{kbp}$ of the transcription start site (Fig. 4C) but not at distances greater than 100kbp of the transcription start site, we defined a cutoff distance of $100 \mathrm{kbp}$ to mark genes whose expression levels are at least in part regulated by the activation and binding of HIF $1 \alpha$ to proximal regulatory sites. Thus, 96 of the 219 upregulated genes and 106 of the 307 downregulated genes contain HIF1 $\alpha-$ DNA binding complexes within 100kbp of the transcription start site (Fig. 4J).

Collectively, these data establish a significant relationship between HIF1 $\alpha$-DNA binding complexes to proximal gene regulatory regions and control of specific gene expression by HIF1 $\alpha$ in lens cells. Interestingly, HIF1 $\alpha$ acts as both an activator and suppressor of gene expression in lens cells consistent with the features of lens cell differentiation that include both activation and repression of specific genes $[43,52,53]$.

\section{Integrated CUT\&RUN and RNA-seq analysis reveals a requirement for HIF1a in the regulation of previously established as well as novel genetic pathways implicated in lens differentiation, homeostasis, structure and function}

HIF1 $\alpha$ and hypoxia are known to control numerous cellular processes including glycolysis, cell cycle and apoptosis [54-56]. Based on the integrated analysis of HIF1 $\alpha$-DNA binding complexes identified by CUT\&RUN and transcriptional regulation by RNAseq, we defined genes as HIF1 $\alpha$-dependent targets if they were significantly induced or repressed upon HIF $1 \alpha$ activation and contained at least one HIF1 $\alpha$ DNA binding complex within 100kbp of the TSS. Employing these criteria, 202 genes were HIF1 $\alpha$ dependent. Of these genes, 62 were previously established as regulated by hypoxia and/or HIF1 $\alpha$ (Fig. 5A, Table S3) in non-lens tissues [57] while 140 genes were novel (Fig. 5B, Table S3).

To elucidate the cellular processes and genetic pathways specific for HIF1 $\alpha$ activation in the lens, we used Enrichr and MSigDB to identify significantly enriched processes and pathways associated with HIF $1 \alpha$-activated and repressed genes. Analysis of HIF1 $\alpha$-dependent activation pathways revealed a wide variety of previously established key lens pathways associated with lens homeostasis and maturation including activation of glycolysis [58], TNF-alpha signaling via NFKB $[59,60]$, reactive oxygen species pathway [36], mTORC1 signaling [37], epithelial-mesenchymal transition [61-64], heme metabolism [65, 66], UV response [58], and apoptotic pathways [67-69] (Fig. 6A and B, Table S4). By contrast, analysis of HIF1 $\alpha$ dependent repressed pathways revealed a wide variety of previously established key lens pathways associated with Notch signaling [70-72], Wnt signaling [73-75], and maintenance of epithelial phenotype [53, 76] (Fig. 6A and B, Table S4). The identification of these pathways suggests a novel HIF1 $\alpha$-dependent regulation of critical lens pathways governing lens homeostasis and maturation.

In addition to these previously established lens pathways a large number of novel pathways without previously established lens functions were also revealed. Of the upregulated genes, the novel enriched pathways included but are not limited to the IL-2/STAT5 signaling pathway while the novel repressed pathways included those involved in adipogenesis, telomerase, KRAS, and FoxO family signaling (Fig. 6A and B, Table S4). 


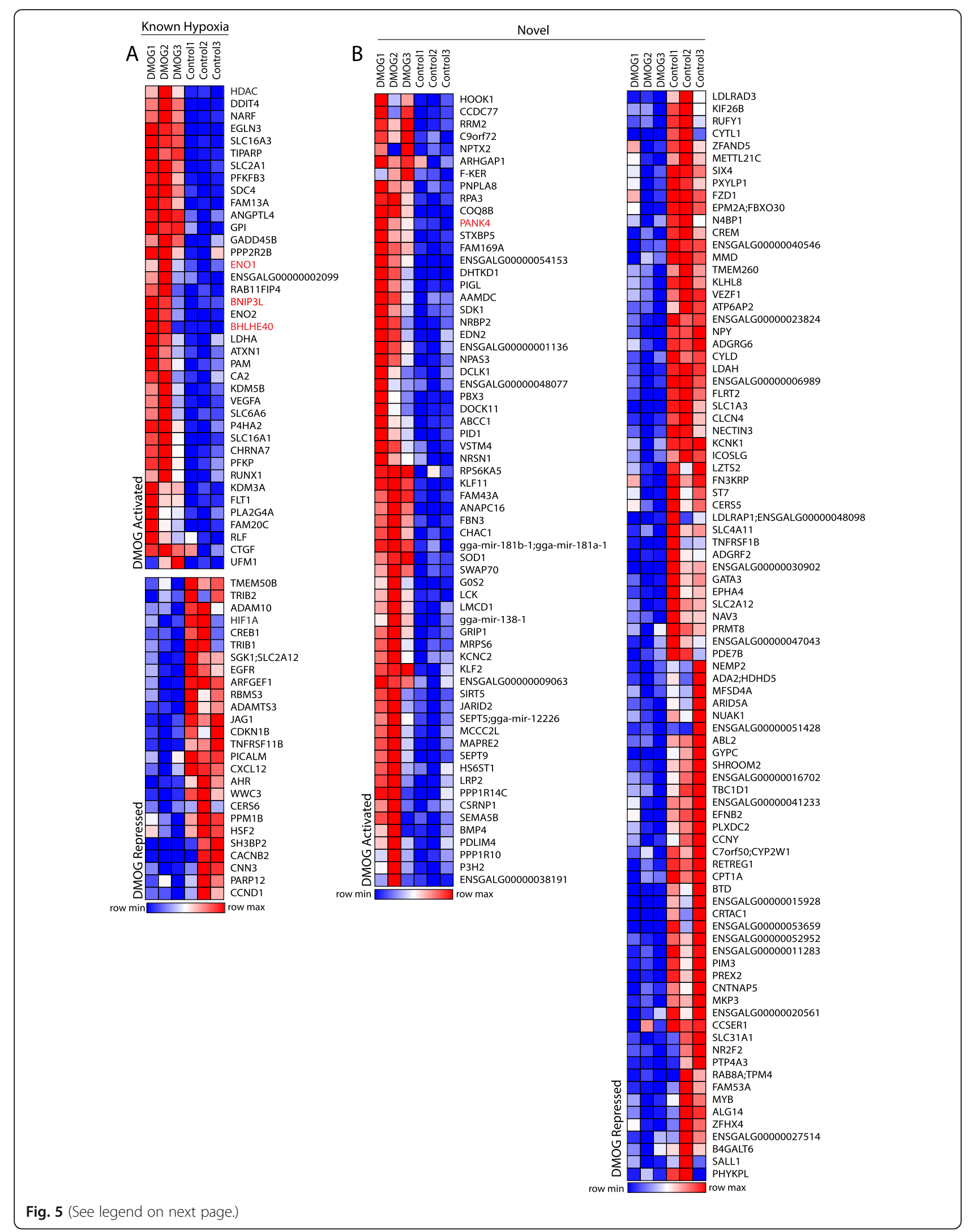


(See figure on previous page.)

Fig. 5 Integrated CUT\&RUN and RNA-seq analysis identifies previously established and novel HIF1a-dependent lens targets. A Heatmap of significantly upregulated $(\log 2 \mathrm{FC}>0.7, p<0.05)$ and downregulated $(\log 2 \mathrm{FC}<-0.7, p<0.05)$ genes with a HIF1a-DNA binding complex that are known to be regulated by hypoxia from [57]. Level of Red indicates higher gene expression levels, and level of blue indicates lower gene expression levels. B Heatmap of significantly upregulated $(\log 2 \mathrm{FC}>0.7, p<0.05)$ and downregulated $(\log 2 \mathrm{FC}<-0.7, p<0.05)$ genes with a HIF1a-DNA binding complex that are not previously known to be regulated by hypoxia from [57]. Red indicates higher gene expression levels, and blue indicates lower gene expression levels

In addition to novel pathways a wide-variety of specific HIF1 $\alpha$-induced genes were also identified including ENO1, PANK4, and BHLHE40. ENO1 is a multifunctional protein that is both a lens structural crystallin and is involved in glucoses metabolism [77, 78] (Fig. 6C). PANK4 has been linked to autosomal dominant congenital cataracts [79] (Fig. 6D) and BHLHE40 is a transcriptional repressor also involved in $\mathrm{NOTCH}$ signaling (Fig. 6E). Other HIF1 $\alpha$-induced genes include ANAPC16 that coordinates lens differentiation through formation of the anaphase-promoting complex [80] and BMP4 that plays a well-established role in lens development [74, 81]. Finally, the chromatin remodeling enzymes HDAC1, KDM3A KDM5A were activated by HIF1 $\alpha$ and their induction could be important for the lens differentiation program (Table S3). Future functional analysis of these genes and pathways will likely reveal novel requirements in essential HIF1 $\alpha$-regulated lens processes and their identification here provides insight into their potential roles in other more complex tissues.

\section{Discussion}

A major feature of the developing and mature eye lens is the presence of an oxygen gradient that parallels the naturally occurring surface to core differentiation of immature lens epithelial cells into mature transparent fiber cells [5]. Based on these lens features, we hypothesized that hypoxia-activation of HIF $1 \alpha$ could regulate lens gene expression levels required to achieve the mature form and function of lens fiber cells. Consistently, a previous study showed disrupted lens structure upon lensspecific deletion of HIF1 $\alpha$ that included dissociation of lens fiber cells, extensive lens fiber cell vacuolization and disintegration of the entire lens shortly after birth [82]. Consistent with an essential role for HIF1 $\alpha$ in lens structure and function, we established that both hypoxia and activation of HIF1 $\alpha$ are required for the elimination of non-nuclear organelles during lens fiber cell formation through HIF1 $\alpha$-dependent activation of the mitophagy protein BNIP3L [8].

Despite the previously established requirements for HIF1 $\alpha$ in lens fiber cell organelle removal and structure, the range and spectrum of lens genetic pathways governed by HIF $1 \alpha$ have not been identified. To identify these pathways and their sub-components, we employed a multiomics approach using CUT\&RUN [34, 35] to identify and map the genomic complement of HIF1 $\alpha$ DNA binding complexes in the lens, RNA-seq to identify gene expression changes directly corresponding with specific HIF1 $\alpha$-DNA binding complexes and ATAC sequencing data to examine the chromatin accessibility of the identified genes [43].

Our analysis identified 8375 HIF1 $\alpha$-DNA binding complexes in the lens genome. HIF1 $\alpha$-DNA binding complexes were more likely to cluster near TSS compared to a computer-generated random distribution of HIF1 $\alpha$-DNA binding complexes $\left(p<2.2 \times 10^{-16}\right) .2576$ (30.8\%). HIF1 $\alpha$-DNA binding complexes were mapped to regions within $10 \mathrm{kbp}$ of the nearest TSS. Consistent with the specificity of these HIF1 $\alpha$-DNA binding complexes, the HIF $1 \alpha$ consensus sequence motif (5'RCGTG-3') was highly enriched in the identified HIF1 $\alpha$-bound genomic regions $\left(\mathrm{E}<3.6 \times 10^{-111}\right)$. Collectively, these results suggest an important role for HIF $1 \alpha$ in the regulation of multiple lens pathways and genes. Consistent with HIF1 $\alpha$ playing an important role in lens gene regulation, 1186 (14.2\%) HIF1 $\alpha$-DNA binding complexes were localized to regions of open chromatin and the HIF $1 \alpha$ consensus sequence motif was enriched in the identified open chromatin regions [43].

CUT\&RUN has been shown to outperform traditional ChIP-seq methods in resolution, efficiency, and data quality [34]. Therefore, we chose CUT\&RUN as a robust method to detect and map HIF1 $\alpha$-DNA binding complexes across the chick lens genome. We are confident that our CUT\&RUN mapping is accurate since it replicated our previous finding using ChIP-qPCR that HIF1 $\alpha$ binds to a $5^{\prime}$ proximal regulatory region of the Gallus gallus BNIP3L gene upon HIF1 $\alpha$ activation [8]. Analysis of all HIF1 $\alpha$-DNA binding complexes indicated an enriched HIF1 $\alpha$ signal and motif analysis of the identified HIF1 $\alpha$-DNA binding complexes confirmed the HIF1 $\alpha$ binding consensus sequence as the most significantly enriched motif. To our knowledge, this study is the first CUT\&RUN analysis of HIF1 $\alpha$.

Of the genes containing HIF1 $\alpha$-DNA binding complexes within 100kbp from the TSS, 96 genes were transcriptionally activated in association with HIF $1 \alpha$ binding $(\log 2 \mathrm{FC}>0.6, p<0.05)$ while 106 genes were transcriptionally repressed in association with HIF1 $\alpha$ binding $(\log 2 \mathrm{FC}<-0.6, p<0.05)$. This relationship was statistically significant for both upregulated genes $\left(\chi^{2}\right.$ test $p<$ 


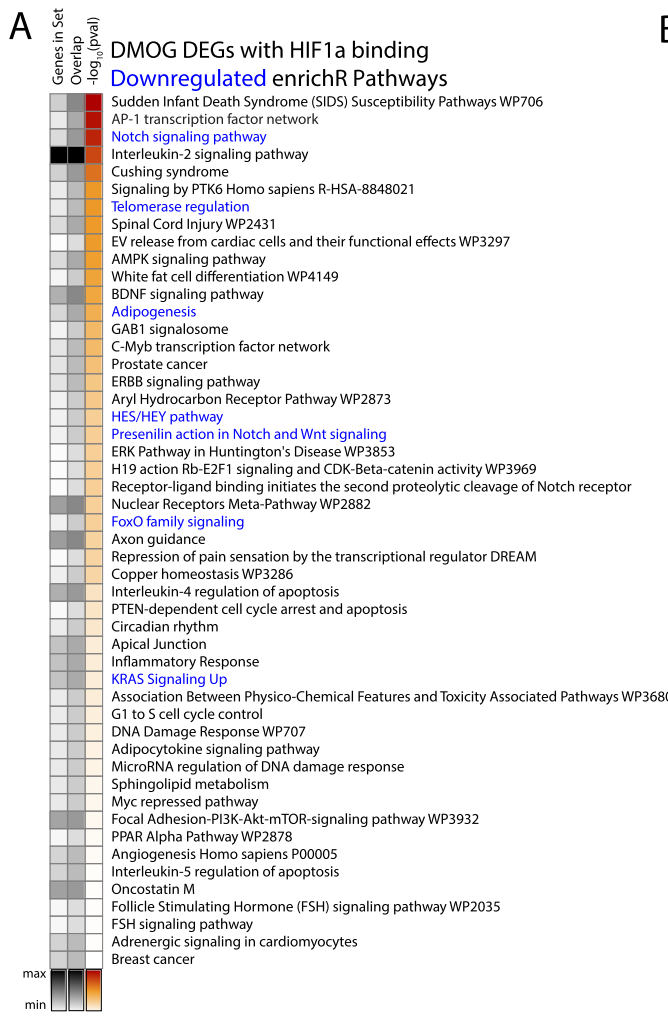

$$
\text { it }
$$

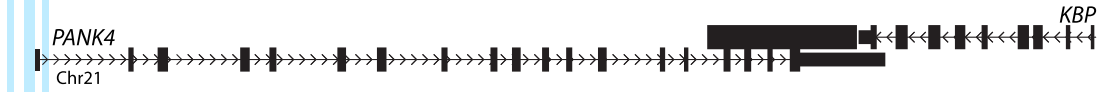

IgG CUT\&RUN

OCRs प्य

\section{E}

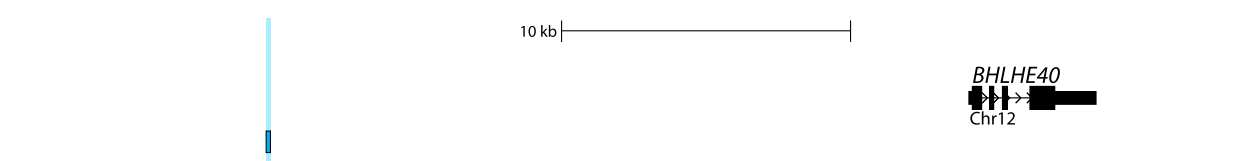

HIF1a CUT\&RUN

IgG CUT\&RUN

OCRs

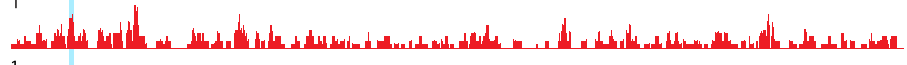

1

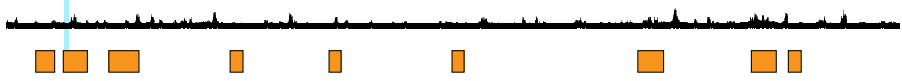

Fig. 6 (See legend on next page.) 
(See figure on previous page.)

Fig. 6 CUT\&RUN and RNA-seq analysis identifies HIF1a-dependent pathways critical for lens structure, homeostasis, metabolism, and

differentiation: A Genes with a HIF1a-DNA binding complex that are significantly downregulated (log2FC $<-0.7, p<0.05)$ were input into Enrichr to elucidate significantly associated biological pathways and processes. The top 50 most statistically significant non-redundant pathways are shown. B Genes with a HIF1a-DNA binding complex that are significantly upregulated (log2FC $>0.7, p<0.05$ ) were input into Enrichr to elucidate significantly associated biological pathways and processes. The top 50 most statistically significant non-redundant pathways are shown. C-E CUT\&RUN tracks of HIF1a (red) and IgG negative control (black) within the genomic region encompassing the Gallus gallus genes ENO1 (C), PANK4 (D), and BHLHE40 (E). The vertical light blue highlight and light blue box indicates a HIF1a-DNA binding complex in the proximal promoter of the gene. The orange track shows the combined chromatin accessibility map representing a combination of the differentiation stage-specific chromatin accessibility tracks obtained from [43] indicating regions of open chromatin in whole chick lens tissue

$0.001)$ and downregulated genes $\left(\chi^{2}\right.$ test $\left.p<0.01\right)$. Many of the genes identified as activated by HIF1 $\alpha$ in lens cells are associated with pathways critical for lens homeostasis, structure and transparency including glycolysis [58], TNF-alpha signaling via NFKB $[59,60]$, reactive oxygen species pathway [36], mTORC1 signaling [37], epithelialmesenchymal transition [61-64], heme metabolism [65, 66], UV response [58], and apoptotic pathways [67-69].

A striking feature of the data is that an almost equal number of lens genes are repressed upon HIF1 $\alpha$ binding suggesting that HIF1 $\alpha$ acts as both an activator and a repressor of lens gene expression. Although many previous studies have identified HIF1 $\alpha$ as a transcriptional repressor of individual genes [83-86], to our knowledge this is the first study to identify HIF $1 \alpha$ as a genome-wide repressor [87].

Many of the HIF1 $\alpha$-repressed genes identified in this study are associated with Wnt signaling, lipid metabolism, and cell adhesion (Table S3). These pathways have previously been implicated in lens cell differentiation and homeostasis [62, 74, 75, 88-92]. This novel finding suggests a role for HIF1 $\alpha$-dependent repression of these pathways to regulate lens differentiation. Consistently, previous studies have shown that HIF1 $\alpha$ represses specific genes associated with Wnt signaling in skeletal muscle and osteoblasts [93, 94] and other studies have shown that both HIF1 and HIF2 reduce expression of enzymes needed for fatty acid breakdown in lipid metabolism [95].

In addition to establishing HIF1 $\alpha$ as both an activator and a repressor in lens cells, our analysis also identified a novel association between gene regulation and the distance of HIF $1 \alpha$-DNA binding complexes relative to TSS's of activated or repressed genes. Specifically, HIF1 $\alpha$ binding to regions within $3 \mathrm{kbp}$ of gene TSS's is significantly associated with gene activation. Conversely, HIF1 $\alpha$ binding to more distal regions between $3 \mathrm{kbp}$ $10 \mathrm{kbp}$ of gene TSS's is significantly associated with gene repression. This difference has implications for the mechanisms underlying HIF1 $\alpha$ control of gene expression in the lens and likely a wide-variety of other tissues. It is possible that HIF1 $\alpha$-DNA binding complexes within $3 \mathrm{kbp}$ of TSS's promote open complex formation through interactions with other transcription factors and transcriptional co-activators that are required for HIF $1 \alpha$ activation including P300, CBP, and $\operatorname{HIF} 1 \beta[18,19,21]$. Conversely, distant HIF1 $\alpha$-DNA binding complexes more than $3 \mathrm{kbp}$ from TSS's may repress open complex formation of gene expression by recruiting these transcriptional regulators away from TSS's. These possibilities are consistent with previous studies linking the action of transcription factors with their binding relative to the TSS whether proximal or distal $[96,97]$. To our knowledge, the present study is the first to-date to find a statistically significant association between genome wide HIF1 $\alpha$ binding site distances and activation or repression of multiple genes.

Many of the identified HIF1 $\alpha$-dependent genes also have well established functions critical for lens cell metabolism, structure, transparency, differentiation, and development. An autosomal dominant mutation in the identified HIF1 $\alpha$-activated PANK4 gene is associated with congenital posterior cataract [79] and is therefore critical for lens transparency. The HIF $1 \alpha$-activated ENO1 gene (tau crystallin) is both a lens structural protein and a glycolytic enzyme [77]. BNIP3L, BMP4, GATA3, CDKN1B, HES5, JAG1, and VEGFA all play important roles in lens cell development and differentiation (Table S3) [8, 70, 74, 81, 98-105]. Therefore, this study suggests that activation of HIF $1 \alpha$ in the lens plays a crucial role in maintaining these important lensspecific functions.

Many of the identified HIF1 $\alpha$-dependent genes also have well established functions critical for mitochondria biogenesis, structure, function, metabolism, and homeostasis (Table S5). The HIF $1 \alpha$-induced gene BNIP3L is required for elimination of mitochondria, endoplasmic reticulum, and golgi apparatus during lens fiber cell differentiation $[7,8]$. SOD1 was found to be induced, it is involved in protection against reactive oxygen species in lens cells $[106,107]$ and plays a role in mitophagy during myoblast differentiation [108]. SIRT5, is involved in regulation of acetylation of the lens chaperone protein $\alpha$-crystallin [109] and regulates acylation of mitochondrial proteins involved in the activation of mitochondrial function in adipose-derived mesenchymal stem cells 
[110]. Therefore, this study suggests that activation of HIF1 $\alpha$ in the lens is critical for the regulation of several mitochondria-associated functional proteins that control mitophagy, protection from reactive oxygen species, and mitochondrial biogenesis.

This study focused on responses of primary lens cells to a chemical activator of HIF1 $\alpha$. However, gene expression in the actual lens is complicated by regional differences in gene expression and the hypoxic gradient of the lens itself. Therefore, further analysis of the gene expression patterns detected in the present study and the role of HIF $1 \alpha$ in their regulation will need to be evaluated in future whole lens analysis. Nevertheless, we are confident that the majority of genes detected will have functional consequences in the lens and consistently the BNIP3L gene that has been shown to be expressed in lens fibers to initiate organelle degradation upon binding of HIF $1 \alpha$ [8] was found in the present study to both exhibit activated expression and binding of HIF $1 \alpha$.

Additionally, the data also identify the HIF $1 \alpha$ gene as a significantly repressed gene upon HIF $1 \alpha$ activation. This has also been observed in other model systems $[111,112]$ and likely represents a negative feedback loop to acutely regulate the expression of genes by HIF $1 \alpha$. In the eye lens, this might be especially important for HIF1 $\alpha$-mediated regulation of lens fiber cell remodeling and maturation.

In addition to identifying known HIF1 $\alpha$-dependent genes, the present analysis also identified 151 novel HIF1 $\alpha$-dependent genes. These include but are not limited to JARID2, BMP4, SIX4, GATA3, ARID5A. These genes are involved in metabolism, chromatin remodeling, development and differentiation of a variety of tissues and cell types (Table S3). Their identification suggests novel HIF1 $\alpha$-dependent roles of the genes in lens and other tissues and suggest novel functions for HIF1 $\alpha$.

Although 202 genes showed a direct relationship between binding of HIF1 $\alpha$ and gene activation or repression, an additional 324 genes exhibited activated or repressed gene expression upon HIF1 $\alpha$ activation in the absence HIF1 $\alpha$ binding. These results suggest that HIF $1 \alpha$ acts to regulate downstream events that control expression of these genes including downstream transcription factors or chromatin remodeling proteins encoded by BHLHE40, HDAC1, JARID2, KDM3A, and $K D M 5 B$ (Table S3) detected in the present report and previously established to be regulated by HIF1 $\alpha$ [57]. These downstream factors could activate or repress expression of these genes by altering chromatin accessibility.

Four thousand five hundred nine genes that exhibited HIF1 $\alpha$ binding did not exhibit altered expression levels even though they were the nearest neighbor to HIF $1 \alpha$ binding sites extending out to $100 \mathrm{kbp}$ away from cognate TSS's. This is not uncommon, as many previous studies have found that not all transcription factor binding sites are associated with active changes in gene expression $[97,113]$ and it is possible that activation or repression of these genes by HIF1 $\alpha$ is dependent on the presence of additional transcription factors and/or coactivators/co-repressors not present or active under the conditions of the present study. Alternatively, the data could indicate a role for HIF1 $\alpha$ in chromatin structure and/or maintenance and future studies will be needed to address these possibilities.

Although this paper specifically focuses on binding and activation of HIF1 $\alpha$, the hypoxic environment of the lens is likely to activate additional hypoxia-regulated processes via other factors [18]. For example p53 that is hypoxia-regulated is known to be involved in HSF4dependent regulation of lens fiber cell differentiation [114]. Further analysis will be required to identify additional hypoxia-regulated lens transcriptional activators and functional pathways. Indeed in the present study, 519 of the 5071 (10.23\%) non-DEGs with HIF1 $\alpha$ binding sites have known associations with hypoxia and it is possible that these genes might be regulated by hypoxia but not HIF $1 \alpha$.

\section{Conclusions}

Collectively, the present report establishes a functional genomic map of novel HIF1 $\alpha$-regulated genes of the eye lens and supports the hypothesis that hypoxia and HIF1 $\alpha$-dependent gene regulation is critical towards achieving mature lens structure and transparency. The data also establish HIF $1 \alpha$ as both an activator and repressor of lens gene expression, reveal novel HIF1 $\alpha$ DNA complex features, confirm previously established HIF1 $\alpha$ targets and identify novel HIF $1 \alpha$ targets that likely are important for the formation and function of the lens and possibly other tissues.

\section{Methods}

\section{Primary lens cell culture}

Primary chick lens epithelial cell cultures were prepared from the lenses of Embryonic day 10 (E10) White Leghorn embryonated chicken eggs (Charles River Laboratories, Storrs, CT) as previously described [36]. Briefly, primary lens cells were isolated from chicken lenses by trypsinization and agitation. Cells were plated onto dishes coated with mouse laminin (Invitrogen, prod no: 23017-015) and cultured in Medium 199 (Invitrogen, prod no: 11150) supplemented with 10\% FBS (Invitrogen, prod no: 16140-071) and penicillin-streptomycin antibiotic mix (50 units/ml; Invitrogen, prod no: 15140 122). The resulting primary lens cells were incubated for 
2 days at $37^{\circ} \mathrm{C}$ in the presence of $5 \% \mathrm{CO}_{2}$ before treatment with DMOG as described below.

\section{Analysis of BNIP3L gene expression in chick lens epithelial cell culture}

BNIP3L transcript levels were evaluated in RNA isolated from 100,000 primary lens epithelial cells. BNIP3L transcript levels were measured by RT-PCR using the SuperScript $^{\oplus}$ III one-step RT-PCR system with Platinum Taq polymerase (Invitrogen) according to the manufacturer's instructions with $\beta$-actin as control. $100 \mathrm{ng}$ of total RNA was assayed following isolation from lens epithelial cells treated or not for $4 \mathrm{~h}$ with $1 \mathrm{mM}$ DMOG. BNIP3L transcripts were amplified for 25 PCR cycles with a $54{ }^{\circ} \mathrm{C}$ annealing temperature and the primer sequences: Forward primer - GCAATGGCAATAGCAATGAT and reverse primer - ATGTAGATGCCTAGTCCCAA. $\beta$-actin transcripts were amplified for 25 PCR cycles with a $58{ }^{\circ} \mathrm{C}$ annealing temperature and the primers sequences: Forward primer - AGCCATCTTTCTTGGGTATGGA and reverse primer - AATCCTGAGTCAAGCGCCAA. The RT-PCR conditions employed were as described in [8]. Conditions were optimized for the amount of RNA used and the number of cycles employed to ensure linear amplification. Statistical significance was determined by student's t-test.

\section{CUT\&RUN on DMOG-treated lens cells and bioinformatics analysis}

Primary lens cells were treated with the HIF $1 \alpha$ activator dimethyloxalllyl glycine (DMOG, Santa Cruz Biotechnology, prod no: sc200755) (1 mM) for $4 \mathrm{~h}$ at $37^{\circ} \mathrm{C}$. DMOG is a cell permeable competitive inhibitor of prolyl hydroxylase domain-containing proteins such as the PHDs. DMOG has been shown to activate HIF1 $\alpha$, under normoxic $\left(21 \% \mathrm{O}_{2}\right)$ conditions in a wide variety of cell types $[115,116]$ including lens cells [8]. DMOG is a widely employed activator of HIF1 $\alpha$ through its ability to inhibit prolyl hydroxylase enzymes resulting in the prevention of HIF $1 \alpha$ degradation through the proteasomal pathway in the presence of oxygen $[115,116]$. Since DMOG inhibits prolyl hydroxylases that could be involved in the regulation and degradation of other lens proteins, it is possible that DMOG could influence other lens functions in addition to activation of HIF1 $\alpha$. However, since this study focused on altered gene expression directly linked with the presence of DMOG dependent HIF1 $\alpha$ DNA complexes we are confident that our results are at least specific for HIF1 $\alpha$ DNA binding and are unlikely to result from HIF1 $\alpha$-independent effects of DMOG that might occur in lens cells.

Cleavage Under Targets \& Release Using Nuclease (CUT\&RUN) [34, 35] was performed on unfixed permeabilized primary lens cells incubated with a HIF1 $\alpha$ - specific ChIP grade antibody (Abcam, ab2185) and an IgG negative control antibody (Invitrogen, prod no: 10500c) to elucidate genome-wide HIF1 $\alpha$-DNA binding complexes. The protocol was adapted from Meers et al., 2019 [117]. Briefly, primary lens cells were harvested, counted, and pooled into biological duplicates of 500, 000 cells each and resuspended in $1.5 \mathrm{ml}$ Wash Buffer without Digitonin (20 mM HEPES pH 7.5, $150 \mathrm{mM}$ $\mathrm{NaCl}, 0.5 \mathrm{mM}$ Spermidine, Protease Inhibitor). After three rounds of washing and centrifuging for $3 \mathrm{~min}$ at $600 \mathrm{~g}$, the resuspended cells were washed in $1 \mathrm{ml}$ wash buffer and ConA-coated magnetic beads (Bangs Labroatories, prod no: BP531, $10 \mu \mathrm{l}$ per sample) were added followed by gentle rotation at room temperature for 10 min. Each sample was divided into two equal volumes and the supernatants removed using a magnet stand. $150 \mu \mathrm{l}$ of antibody buffer with $0.1 \%$ final concentration digitonin was added to each aliquot with gentle agitation to permeabilize the cells. For each biological sample, one aliquot of ConA-bound cells was incubated with ChIPgrade HIF $1 \alpha$ antibody and the other aliquot was incubated with IgG antibody at a 1:100 dilution and rotated at $4{ }^{\circ} \mathrm{C}$ overnight. HIF $1 \alpha$ antibody specificity was confirmed by western analysis of primary lens cell nuclear extract and by ChIP-qPCR published in a previous study [8]. Antibody-bound ConA-bound cells were washed twice with $1 \mathrm{ml}$ wash buffer with $0.1 \%$ digitonin. The supernatant was removed and $150 \mu \mathrm{l}$ of Protein AMNase $(700 \mathrm{ng} / \mathrm{mL}$ final concentration, Addgene \#123461) [117] in wash buffer with digitonin was added to the pellet with gentle agitation and the mix rotated at $4{ }^{\circ} \mathrm{C}$ for $1 \mathrm{~h}$. Cells were washed twice with $1 \mathrm{ml}$ of digitonin wash buffer and once with $1 \mathrm{ml}$ low salt rinse buffer (20 mM HEPES pH 7.5, 0.5 mM Spermidine, 0.05\% Digitonin). The supernatant was removed and $200 \mu \mathrm{l}$ of icecold incubation buffer (3.5 mM HEPES pH 7.5, $10 \mathrm{mM}$ $\mathrm{CaCl} 2,0.05 \%$ Digitonin) added with gentle agitation. The resulting samples were incubated on ice for $5 \mathrm{~min}$ before removing the supernatant using the magnet stand followed by the addition of $200 \mu \mathrm{l}$ STOP buffer $(170 \mathrm{mM}$ $\mathrm{NaCl}, 20 \mathrm{mM}$ EGTA, 0.05\% Digitonin, 50 $\mathrm{g} / \mathrm{mL}$ RNAse A, $25 \mu \mathrm{g} / \mathrm{mL}$ Glycogen) with gentle agitation. The samples were incubated for $30 \mathrm{~min}$ at $37^{\circ} \mathrm{C}$ to release CUT\&RUN fragments. Following incubation, the supernatant containing CUT\&RUN fragments was transferred to a fresh microcentrifuge tube. CUT\&RUN fragments were treated with $2 \mu \mathrm{l} 10 \%$ SDS and $2.5 \mu \mathrm{l}$ Proteinase K $\left(20 \mathrm{mg} / \mathrm{ml}\right.$ ) for $1 \mathrm{~h}$ at $50{ }^{\circ} \mathrm{C}$. DNA was isolated by standard Phenol-Chloroform extraction using Qiagen MaXtract tubes, and the DNA pellet resuspended in $30 \mu \mathrm{l} 1$ $\mathrm{mM}$ Tris- $\mathrm{HCl} \mathrm{pH} 80.1 \mathrm{mM}$ EDTA. Library prep was carried out using the NEBNext Ultra II DNA Library Prep Kit for Illumina (NEB E7645) following the manufacturer's instructions [118]. Samples were resuspended 
in $15 \mu \mathrm{l}$ of $0.1 \mathrm{x}$ TE Buffer. Libraries were pooled and PE50 sequencing on an Illumina Hiseq platform was performed.

Reads were trimmed with Trimmomatic [119] with the following settings (ILLUMINACLIP: 2:15:4:4:true SLID INGWINDOW:4:15 MINLEN:25) and aligned to the galgal6 genome (ensemble version 96) using Bowtie2 [120] with the following settings: (--end-to-end,--dove-tail,-phred33). Samtools [121] was used to retain fragments $<120 \mathrm{bp}$, and to remove reads in mitochondrial DNA and remove reads overlapping low-complexity regions in the Galgal6 genome as defined by the RepeatMasker [122] track in the UCSC genome browser. HIF1 $\alpha$-DNA binding complexes were identified using MACS2 [123, 124 ] by pooling the HIF1 $\alpha$ BAM files versus the pooled IgG BAM files using the following settings: (narrowPeak setting, q value cutoff $0.05,-$-SPMR, --keep-dup auto). MACS 2 on CUT\&RUN samples identified 8375 HIF $1 \alpha-$ DNA binding complexes in the primary chick lens cells (Table S1). Although some studies have detected low levels of HIF1 $\alpha$-DNA binding under normoxic conditions in non-lens tissues [125], we have previously shown that HIF1 $\alpha$ is barely detectable in lens cells in the absence of hypoxia or DMOG activation [8].

\section{RNA-seq on DMOG-treated lens cells and bioinformatics analysis}

Biological triplicates of primary chick lens cells were incubated in the presence or absence of $1 \mathrm{mM}$ DMOG for $4 \mathrm{~h}$ at $37^{\circ} \mathrm{C}$. Total RNA was isolated from primary lens cells using TRIZOL $^{\circ}$ reagent (Invitrogen, prod no: 15593018) according to the manufacturer's instructions. Libraries were prepared following Illumina's TruSeq-stranded-totalRNA-sample preparation protocol. Paired-end sequencing was performed on Illumina's NovaSeq 6000 platform. Cutadapt [126] was used to remove adaptor-contaminated reads, low quality bases and undetermined bases. Reads were mapped to galgal6 genome (ensemble version 96) using Bowtie2 [120] and HISAT2 [127]. The mapped reads were assembled using StringTie [128]. Comprehensive transcriptomes were generated using gffcompare and StringTie [128]. The R package edgeR [129] was used to estimate the expression levels of all transcripts and to identify differentially expressed genes ( $\log 2$ fold change FPKM $>0.6$ or $<-0.6)$ with parametric F-test comparing nested linear models $(p<0.05)$. Five hundred twenty-six genes were found to be differentially expressed in DMOG-treated primary lens cells relative to untreated primary lens cell samples (Table S2).

\section{Additional bioinformatics methods}

MACS2 generated bedgraph files for the HIF1 $\alpha$ and IgG CUT\&RUN samples were converted to BIGWIG format and visualized in UCSC Genome Browser (https://
genome.ucsc.edu/s/jdisatha/CUTRUN_Lens_HIF1A) [130]. Genomic coordinates of chick lens open chromatin regions mapped by ATAC sequencing [43] were lifted to galgal6 using UCSC Genome Browser liftover tool. HIF1 $\alpha$-DNA binding complexes identified by CUT\&RUN that are also contained within previously identified open chromatin regions [43] are noted in Table S1.

The Bedtools [131] Shufflebed function was used to generate a negative control background of HIF1 $\alpha$-DNA binding complexes randomly distributed across the galgal6 genome using default settings.

The ChIPseeker [132], bedtools [131] and Closestbed tools were used to identify relative distances of HIF $1 \alpha$ DNA binding complexes to the nearest gene transcription start sites (Table S1).

Deeptools [133], plotProfile and plotHeatmap functions default settings were used to generate the profile and heatmap in Fig. 2A. Each site identified as a HIF1 $\alpha$ binding site by the MACS2 bioinformatics tool is overlayed in a window $+/-1000 \mathrm{bp}$ around the peak of the binding site. The heatmap and profile plot generated by deepTools indicate the signal strength of the HIF1 $\alpha$ CUTandRUN signal and compares it to the IgG negative control signal across all of the identified HIF1 $\alpha$ binding regions.

MEME-suite [134] DREME tool [135] default settings were used to identify short-ungapped overrepresented sequence patterns in the HIF1 $\alpha$-DNA binding complexes at genomic regions identified by CUT\&RUN.

HIF1 $\alpha$-dependent genes identified by our multiomic analysis were cross-referenced with hypoxiadb [57] to elucidate previously known hypoxia-dependent genes compared to novel HIF1 $\alpha$-dependent genes.

Enrichr [136-138] and Msigdb [139, 140] tools were used to identify significantly enriched processes and pathways associated with the identified HIF1 $\alpha$ dependent genes.

All heatmaps shown were generated with the Morpheus Bioinformatics tool (https://software. broadinstitute.org/morpheus/).

\section{Statistical analysis}

Chi-squared goodness-of-fit test was performed in $\mathrm{R}$ version 3.6.3 using the chisq.test() function to test the null hypothesis that the distribution of HIF1 $\alpha$ binding sites were similar to what is expected from a random distribution of sites generated by bedtools ShuffleBed. (Figs. 2D and F and 3A). All other chi-square tests were performed to test against the null hypothesis of no significant differences in number of genes with HIF $\alpha$ binding sites categorized in various different ways (Fig. 4B, C, E, F). Bonferroni corrected $p$-values are reported. 


\section{Abbreviations}

CUT\&RUN: Cleavage Under Targets and Release Under Nuclease; ATACseq: Assay for Transposase-Accessible Chromatin sequencing; HIF1a: Hypoxia inducible factor 1 alpha; TSS: Transcription start site; ChIPqPCR: Chromatin immunoprecipitation coupled with quantitative polymerase chain reaction; FPKM: Fragments per kilobase of exon per million fragments mapped; DMOG: Dimethyloxalylglycine

\section{Supplementary Information}

The online version contains supplementary material available at https://doi. org/10.1186/s12864-021-07795-9.

Additional file 1: Table S1. HIF1a binding peaks enriched by CUT\&RUN and detected with MACS2 at $\mathrm{q}<0.05$ in DMOG-treated primary lens cells.

Additional file $\mathbf{2}$ Table S2. Gene expression analysis via RNA-seq of DMOG-treated vs untreated primary lens cells.

Additional file $\mathbf{3}$ Table S3. Gene ontologies, pathways, and select literature references for differentially expressed genes with HIF1a binding.

Additional file 4: Table S4. Enriched gene ontologies and pathways associated with HIF1a-bound upregulated and downregulated genes as determined by MsigDB and Enrichr.

Additional file 5: Table S5. HIF1a-regulated genes with associated mitochondria functions.

Additional file 6: Figure S1. Full length version of the RT-PCR agarose gel from Fig. 1C.

Additional file 7: Figure S2. Second most statistically significant enriched motif in HIF1a-DNA binding regions identified by CUT\&RUN.

\section{Acknowledgements}

Not applicable.

\section{Authors' contributions}

JD Conceived of the studies, performed experiments, analyzed data and participated in writing the manuscript as part of his requirements for graduating from the Florida Atlantic University Integrative Biology-Biomedical Science PhD program; LB Conceived of the studies, performed experiments, analyzed data, participated in writing the manuscript and in funding acquisition; DC analyzed data and participated in writing the manuscript; JK analyzed data and participated in writing the manuscript; BA analyzed data and participated in writing the manuscript; MK Conceived of the studies, analyzed data, participated in writing the manuscript and funding acquisition and directed the work. The author(s) read and approved the final manuscript.

\section{Funding}

This work was supported by the National Institutes of Health, USA, National Eye Institute, USA Grant number EY029708 (MK). Support for Dr. B. Afzali and Dr. D. Chauss was provided in part by NIDDK intramural research program Z1A_DK075149.

\section{Availability of data and materials}

Raw sequencing reads for the CUT\&RUN experiment have been deposited at NCBI-GEO series accession number GSE166626. Raw sequencing reads for the RNA-seq experiment have been deposited at NCBI-GEO series accession number GSE166632.

ATACseq data were obtained from supplemental files from [31].

\section{Declarations}

Ethics approval and consent to participate

Not applicable.

\section{Consent for publication}

Not applicable.

\section{Competing interests}

The authors declare that they have no competing interests.

\section{Author details}

Charles E. Schmidt College of Medicine, Florida Atlantic University, 777 Glades Rd., Boca Raton, FL 33431, USA. ${ }^{2}$ Immunoregulation Section, Kidney Diseases Branch, National Institute of Diabetes and Digestive and Kidney Diseases (NIDDK), NIH, Bethesda, MD 20892, USA. ${ }^{3}$ University of Florida, Gainesville, FL 32611, USA.

Received: 16 February 2021 Accepted: 9 June 2021

Published online: 03 July 2021

\section{References}

1. Bassnett S, Shi Y, Vrensen GFJM. Biological glass: structural determinants of eye lens transparency. Philos Trans R Soc Lond Ser B Biol Sci. 2011;366: 1250-64 The Royal Society. [cited 2019 Feb 6]. Available from: http://www. ncbi.nlm.nih.gov/pubmed/21402584.

2. Lutty GA, McLeod DS. Development of the hyaloid, choroidal and retinal vasculatures in the fetal human eye. Prog Retin Eye Res. 2018;62:58-76.

3. Bassnett $S$, McNulty R. The effect of elevated intraocular oxygen on organelle degradation in the embryonic chicken lens. J Exp Biol. 2003; 206(23):4353-61. https://doi.org/10.1242/jeb.00670.

4. Beebe DC, Shui YB, Siegfried CJ, Holekamp NM, Bai F. Preserve the (intraocular) environment: the importance of maintaining normal oxygen gradients in the eye. Jpn J Ophthalmol. 2014;58(3):225-31. https://doi.org/1 0.1007/s10384-014-0318-4.

5. McNulty R, Wang H, Mathias RT, Ortwerth BJ, Truscott RJW, Bassnett S. Regulation of tissue oxygen levels in the mammalian lens. J Physiol. 2004; 559(Pt 3):883-98.

6. Shestopalov VI, Bassnett S. Expression of autofluorescent proteins reveals a novel protein permeable pathway between cells in the lens core. J Cell Sci. 2000;113(11):1913-21. https://doi.org/10.1242/jcs.113.11.1913.

7. Brennan LA, McGreal-Estrada R, Logan CM, Cvekl A, Menko AS, Kantorow M. BNIP3L/NIX is required for elimination of mitochondria, endoplasmic reticulum and Golgi apparatus during eye lens organelle-free zone formation. Exp Eye Res. 2018;174:173-84. https://doi.org/10.1016/j.exer.2018. 06.003 .

8. Brennan L, Disatham J, Kantorow M. Hypoxia regulates the degradation of non-nuclear organelles during lens differentiation through activation of HIF1a. Exp Eye Res. 2020;198 Academic Press. [cited 2020 Nov 16]. Available from: https://pubmed.ncbi.nlm.nih.gov/32628953/.

9. Chinnadurai G, Vijayalingam S, Gibson SB. BNIP3 subfamily BH3-only proteins: Mitochondrial stress sensors in normal and pathological functions. Oncogene. 2008:S114-27 [cited 2021 May 1]. Available from: https:// pubmed.ncbi.nlm.nih.gov/19641497/.

10. Diwan A, Matkovich SJ, Yuan Q, Zhao W, Yatani A, Brown JH, et al. Endoplasmic reticulum-mitochondria crosstalk in NIX-mediated murine cell death. J Clin Invest. 2009;119:203-12 [cited 2021 May 1]. Available from: https://pubmed.ncbi.nlm.nih.gov/19065046/.

11. Aerbajinai W, Giattina M, Lee YT, Raffeld M, Miller JL. The proapoptotic factor Nix is coexpressed with BCl-xL during terminal erythroid differentiation. Blood. 2003;102:712-7 [cited 2021 May 1]. Available from: https://pubmed.ncbi.nIm.nih.gov/12663450/

12. Novak I, Kirkin V, McEwan DG, Zhang J, Wild P, Rozenknop A, et al. Nix is a selective autophagy receptor for mitochondrial clearance. EMBO Rep. 2010; 11(1):45-51.

13. Sandoval H, Thiagarajan P, Dasgupta SK, Schumacher A, Prchal JT, Chen M, et al. Essential role for Nix in autophagic maturation of erythroid cells. Nature. 2008:454(7201):232-5.

14. Schweers RL, Zhang J, Randall MS, Loyd MR, Li W, Dorsey FC, et al. NIX is required for programmed mitochondrial clearance during reticulocyte maturation. Proc Natl Acad Sci U S A. 2007;104:19500-5 [cited 2021 May 1]. Available from: https://pubmed.ncbi.nlm.nih.gov/18048346/.

15. Zhang J, Ney PA. NIX induces mitochondrial autophagy in reticulocytes. Autophagy. 2008;4:354-6 Taylor and Francis Inc. [cited 2021 May 1]. Available from: https://www.tandfonline.com/action/journallnforma tion?journalCode=kaup20.

16. Diwan A, Koesters AG, Odley AM, Pushkaran S, Baines CP, Spike BT, et al. Unrestrained erythroblast development in Nix-/- mice reveals a mechanism for apoptotic modulation of erythropoiesis. Proc Natl Acad Sci U S A. 2007:104:6794-9 [cited 2021 May 1]. Available from: https://pubmed. ncbi.nlm.nih.gov/17420462/. 
17. Shui Y-B, Arbeit JM, Johnson RS, Beebe DC. HIF-1: an age-dependent regulator of lens cell proliferation. Investig Opthalmology Vis Sci. 2008;49: 4961 [cited 2019 Mar 1]. Available from: http://www.ncbi.nlm.nih.gov/ pubmed/18586877.

18. Cummins EP, Taylor CT. Hypoxia-responsive transcription factors. Pflugers Arch - Eur J Physiol. 2005:450(6):363-71.

19. Kenneth NS, Rocha S. Regulation of gene expression by hypoxia. Biochem J. 2008:19-29 [cited 2020 Nov 16]. Available from: https://pubmed.ncbi.nlm. nih.gov/18651837/.

20. Wenger $\mathrm{RH}$. Cellular adaptation to hypoxia: $\mathrm{O} 2$-sensing protein hydroxylases, hypoxia-inducible transcription factors, and $\mathrm{O} 2$-regulated gene expression. FASEB J. 2002;16(10):1151-62. https://doi.org/10.1096/fj.010944rev.

21. Brahimi-Horn MC, Pouyssegur J. HIF at a glance. J Cell Sci. 2009;122(8):10557. https://doi.org/10.1242/jcs.035022.

22. Solaini G, Baracca A, Lenaz G, Sgarbi G. Hypoxia and mitochondrial oxidative metabolism. Biochim Biophys Acta Bioenerg. 2010;1797(6-7):1171-7.

23. Chauss D, Basu S, Rajakaruna S, Ma Z, Gau V, Anastas S, et al. Differentiation state-specific mitochondrial dynamic regulatory networks are revealed by global transcriptional analysis of the developing chicken lens. Genes Genomes Genetics. 2014;4(8):1515-27.

24. Pugh CW, Ratcliffe PJ. Regulation of angiogenesis by hypoxia: role of the HIF system. Nat Med. 2003:677-84 [cited 2020 Dec 6]. Available from: https://pubmed.ncbi.nlm.nih.gov/12778166/.

25. Luo Y, Teng X, Zhang L, Chen J, Liu Z, Chen X, et al. CD146-HIF-1a hypoxic reprogramming drives vascular remodeling and pulmonary arterial hypertension. Nat Commun. 2019;10 Nature Publishing Group. [cited 2020 Nov 16]. Available from: https://pubmed.ncbi.nlm.nih.gov/31391533/.

26. Meng X, Grötsch B, Luo Y, Knaup KX, Wiesener MS, Chen XX, et al. Hypoxiainducible factor-1 $a$ is a critical transcription factor for $\mathrm{LL}-10$-producing B cells in autoimmune disease. Nat Commun. 2018;9 Nature Publishing Group. [cited 2020 Nov 16]. Available from: https://pubmed.ncbi.nlm.nih.gov/29343 $683 /$.

27. Esteban-Martínez L, Boya P. BNIP3L/NIX-dependent mitophagy regulates cell differentiation via metabolic reprogramming. Autophagy. 2018:915-7 Taylor and Francis Inc. [cited 2020 Nov 16]. Available from: https://pubmed.ncbi. nlm.nih.gov/28614042/.

28. Lindholm ME, Rundqvist $\mathrm{H}$. Skeletal muscle hypoxia-inducible factor-1 and exercise. Exp Physiol. 2016;101:28-32 Blackwell Publishing Ltd. [cited 2020 Nov 16]. Available from: https://pubmed.ncbi.nlm.nih.gov/26391197/.

29. Shao T, Zhao C, Li F, Gu Z, Liu L, Zhang L, et al. Intestinal HIF-1a deletion exacerbates alcoholic liver disease by inducing intestinal dysbiosis and barrier dysfunction. J Hepatol. 2018;69:886-95 Elsevier B.V.. [cited 2020 Nov 16]. Available from: https://pubmed.ncbi.n/m.nih.gov/29803899/.

30. Ashok BS, Ajith TA, Sivanesan S. Hypoxia-inducible factors as neuroprotective agent in Alzheimer's disease. Clin Exp Pharmacol Physiol. 2017:327-34 Blackwell Publishing. [cited 2020 Nov 16]. Available from: https://pubmed.ncbi.nlm.nih.gov/28004401/.

31. Sano M, Minamino $T$, Toko $H$, Miyauchi $H$, Orimo $M$, Qin $Y$, et al. p53induced inhibition of $\mathrm{Hif-1}$ causes cardiac dysfunction during pressure overload. Nature. 2007;446:444-8 Nature Publishing Group. [cited 2020 Nov 16]. Available from: https://pubmed.ncbi.nlm.nih.gov/17334357/.

32. Higgins DF, Kimura K, Bernhardt WM, Shrimanker N, Akai Y, Hohenstein $B$, et al. Hypoxia promotes fibrogenesis in vivo via HIF-1 stimulation of epithelial-to-mesenchymal transition. J Clin Invest. 2007;117:3810-20 [cited 2020 Nov 16]. Available from: https://pubmed.ncbi.nlm.nih.gov/1 8037992/.

33. Dayan F, Roux D, Brahimi-Horn MC, Pouyssegur J, Mazure NM. The oxygen sensor factor-inhibiting hypoxia-inducible factor-1 controls expression of distinct genes through the bifunctional transcriptional character of hypoxiainducible factor-1a. Cancer Res. 2006;66(7):3688-98. https://doi.org/10.1158/ 0008-5472.CAN-05-4564.

34. Skene PJ, Henikoff S. An efficient targeted nuclease strategy for highresolution mapping of DNA binding sites. Elife. 2017;6 eLife Sciences Publications Ltd. [cited 2020 Nov 17]. Available from: https://pubmed.ncbi. nlm.nih.gov/28079019/.

35. Skene PJ, Henikoff JG, Henikoff S. Targeted in situ genome-wide profiling with high efficiency for low cell numbers. Nat Protoc. 2018;13(5):1006-19. https://doi.org/10.1038/nprot.2018.015 Nature Publishing Group.

36. Brennan L, Khoury J, Kantorow M. Parkin elimination of mitochondria is important for maintenance of lens epithelial cell ROS levels and survival upon oxidative stress exposure. Biochim Biophys Acta Mol basis Dis. 2017; 1863:21-32. https://doi.org/10.1016/j.bbadis.2016.09.020.

37. Basu S, Rajakaruna S, Reyes B, Van Bockstaele E, Menko AS. Suppression of MAPKJNKK-MTORC1 signaling leads to premature loss of organelles and nuclei by autophagy during terminal differentiation of lens fiber cells. Autophagy. 2014;10(7):1193-211. https://doi.org/10.4161/auto.28768.

38. Weber GF, Menko AS. Phosphatidylinositol 3-kinase is necessary for lens fiber cell differentiation and survival. Investig Ophthalmol Vis Sci. 2006;47: 4490-9 [cited 2020 Nov 16]. Available from: https://pubmed.ncbi.nlm.nih. gov/17003444/.

39. Boswell BA, Korol A, West-Mays JA, Musil LS. Dual function of TGF $\beta$ in lens epithelial cell fate: implications for secondary cataract. Mol Biol Cell. 2017;28: 907-21 American Society for Cell Biology. [cited 2020 Nov 16]. Available from: https://pubmed.ncbi.nlm.nih.gov/28209733/.

40. VanSlyke JK, Boswell BA, Musil LS. Fibronectin regulates growth factor signaling and cell differentiation in primary lens cells. J Cell Sci. 2018;131 Company of Biologists Ltd. [cited 2020 Nov 16]. Available from: https:// pubmed.ncbi.nlm.nih.gov/30404825/.

41. Musil LS. Primary cultures of embryonic chick lens cells as a model system to study lens gap junctions and fiber cell differentiation. J Membr Biol. 2012; 245:357-68 [cited 2020 Nov 16]. Available from: https://pubmed.ncbi.nlm. nih.gov/22797938/.

42. Buenrostro JD, Wu B, Chang HY, Greenleaf WJ. ATAC-seq: a method for assaying chromatin accessibility genome-wide. Curr Protoc Mol Biol. 2015; 2015:21.29.1-9 Blackwell Publishing Inc. https://doi.org/10.1002/0471142727. mb2129s109.

43. Disatham J, Chauss D, Gheyas R, Brennan L, Blanco D, Daley L, et al. Lens differentiation is characterized by stage-specific changes in chromatin accessibility correlating with differentiation state-specific gene expression. Dev Biol. 2019;453(1):86-104; Elsevier Inc.

44. Bassnett S. The effect of elevated intraocular oxygen on organelle degradation in the embryonic chicken lens. J Exp Biol. 2003;206(23):435361. https://doi.org/10.1242/jeb.00670.

45. Sowter HM, Ratcliffe PJ, Watson P, Greenberg AH, Harris AL. HIF-1dependent regulation of hypoxic induction of the cell death factors BNIP3 and NIX in human tumors. Cancer Res. 2001;61(18):6669-73.

46. Bellot G, Garcia-Medina R, Gounon P, Chiche J, Roux D, Pouyssegur J, et al. Hypoxia-induced autophagy is mediated through hypoxia-inducible factor induction of BNIP3 and BNIP3L via their BH3 domains. Mol Cell Biol. 2009; 29(10):2570-81. https://doi.org/10.1128/MCB.00166-09.

47. Schödel J, Oikonomopoulos S, Ragoussis J, Pugh CW, Ratcliffe PJ, Mole DR. High-resolution genome-wide mapping of HIF-binding sites by ChIP-seq. Blood. 2011;117:e207 Am Soc Hematol Educ. https://doi.org/10.1182/ blood-2010-10-314427.

48. Smythies JA, Sun M, Masson N, Salama R, Simpson PD, Murray E, et al. Inherent DNA -binding specificities of the HIF - 1 a and HIF -2a transcription factors in chromatin. EMBO Rep. 2019;20:e46401 EMBO. [cited 2021 May 4]. Available from: https://www.embopress.org/doi/full/10.15252/embr.2018464 01.

49. Jiang C, Pugh BF. Nucleosome positioning and gene regulation: advances through genomics. Nat Rev Genet. 2009;10:161-72 NIH Public Access. [cited 2019 Feb 6]. Available from: http://www.ncbi.nlm.nih.gov/ pubmed/19204718.

50. Rudnizky S, Malik O, Bavly A, Pnueli L, Melamed P, Kaplan A. Nucleosome mobility and the regulation of gene expression: insights from singlemolecule studies. Protein Sci. 2017;26:1266-77 [cited 2019 Feb 6]. Available from: http://www.ncbi.nlm.nih.gov/pubmed/28329910.

51. Venkatesh S, Workman JL. Histone exchange, chromatin structure and the regulation of transcription. Nat Rev Mol Cell Biol. 2015;16:178-89 [cited 2019 Feb 6]. Available from: http://www.ncbi.nlm.nih.gov/pubmed/25650798.

52. Chauss D, Basu S, Rajakaruna S, Ma Z, Gau V, Anastas S, et al. Differentiation state-specific mitochondrial dynamic regulatory networks are revealed by global transcriptional analysis of the developing chicken lens. G3. 2014;4: 1515-27 [cited 2019 Feb 7]. Available from: http://www.ncbi.nlm.nih.gov/ pubmed/24928582.

53. Sue Menko A. Lens epithelial cell differentiation. Exp Eye Res. 2002:75:48590 Academic Press. [cited 2019 May 28]. Available from: https://www. sciencedirect.com/science/article/pii/S0014483502920579?via\%3Dihub.

54. Greijer AE, Van Der Wall E. The role of hypoxia inducible factor 1 (HIF-1) in hypoxia induced apoptosis. J Clin Pathol. 2004:1009-14 BMJ Publishing Group. https://doi.org/10.1136/jcp.2003.015032. 
55. Koshiji M, Kageyama Y, Pete EA, Horikawa I, Barrett JC, Huang LE. HIF-1a induces cell cycle arrest by functionally counteracting Myc. EMBO J. 2004;23: 1949-56 [cited 2020 Dec 7]. Available from: https://pubmed.ncbi.nlm.nih. gov/15071503/.

56. Del Rey MJ, Valín Á, Usategui A, García-Herrero CM, Sánchez-Aragó M, Cuezva JM, et al. Hif-1a knockdown reduces glycolytic metabolism and induces cell death of human synovial fibroblasts under normoxic conditions. Sci Rep. 2017;7 Nature Publishing Group. [cited 2020 Dec 7]. Available from: https://pubmed.ncbi.nlm.nih.gov/28623342/.

57. Khurana P, Sugadev R, Jain J, Singh SB. HypoxiaDB: a database of hypoxiaregulated proteins. Database. 2013;2013 Oxford University Press. https://doi. org/10.1093/database/bat074.

58. Hejtmancik JF, Riazuddin SA, McGreal R, Liu W, Cvekl A, Shiels A. Lens biology and biochemistry. Prog Mol Biol Transl Sci. 2015;134:169-201.

59. Dudek EJ, Shang F, Taylor A. H2O2-mediated oxidative stress activates NFKB in lens epithelial cells. Free Radic Biol Med. 2001;31:651-8 [cited 2021 Jan 11]. Available from: https://pubmed.ncbi.n/m.nih.gov/11522450/.

60. Ramana KV, Friedrich B, Bhatnagar A, Srivastava SK. Aldose reductase mediates cytotoxic signals of hyperglycemia and TNF-alpha in human lens epithelial cells. FASEB J. 2003;17:315-7 [cited 2021 Jan 11]. Available from: https://pubmed.ncbi.nlm.nih.gov/12490536/.

61. Kubo E, Shibata T, Singh DP, Sasaki H. Roles of TGF $\beta$ and FGF signals in the lens: tropomyosin regulation for posterior capsule opacity. Int J Mol Sci. 2018; MDPI AG. [cited 2021 Jan 11]. Available from: https://pubmed.ncbi. nlm.nih.gov/30304871/.

62. Whitson JA, Zhang X, Medvedovic M, Chen J, Wei Z, Monnier VM, et al. Transcriptome of the GSH-Depleted lens reveals changes in detoxification and EMT signaling genes, transport systems, and lipid homeostasis. Investig Ophthalmol Vis Sci. 2017;58:2666-84 Association for Research in Vision and Ophthalmology Inc. [cited 2021 Jan 11]. Available from: https://pubmed. ncbi.nlm.nih.gov/28525556/.

63. Zhang $Y$, Huang $W$. Transforming growth factor $\beta 1$ (Tgf- $\beta 1$ )-stimulated integrin-linked kinase (ILK) regulates migration and epithelial-mesenchymal transition (EMT) of human lens epithelial cells via nuclear factor KB (NF-kB). Med Sci Monit. 2018;24:7424-30 International Scientific Information, Inc. [cited 2021 Jan 11]. Available from: https://pubmed.ncbi.nlm.nih.gov/303323 98/.

64. Li X, Wang F, Ren M, Du M, Zhou J. The effects of c-Src kinase on EMT signaling pathway in human lens epithelial cells associated with lens diseases. BMC Ophthalmol. 2019;19 BioMed Central Ltd. [cited 2021 Jan 11]. Available from: https://pubmed.ncbi.nlm.nih.gov/31703690/.

65. Ju MT, Hui LD, Zhi HS, Ye Z, Li P, Zhai W, et al. Nrf2 protects human lens epithelial cells against $\mathrm{H} 2 \mathrm{O} 2$-induced oxidative and ER stress: the ATF4 may be involved. Exp Eye Res. 2018;169:28-37 Academic Press. [cited 2021 Jan 11]. Available from: https://pubmed.ncbi.n/m.nih.gov/29421327/.

66. Ma T, Chen T, Li P, Ye Z, Zhai W, Jia L, et al. Heme oxygenase-1 (HO-1) protects human lens epithelial cells (SRA01/04) against hydrogen peroxide (H2O2)-induced oxidative stress and apoptosis. Exp Eye Res. 2016;146:31829 Academic Press. [cited 2021 Jan 11]. Available from: https://pubmed.ncbi. nlm.nih.gov/26992777/.

67. Wride MA. Lens fibre cell differentiation and organelle loss: many paths lead to clarity. Philos Trans R Soc B Biol Sci. 2011;366(1568):1219-33. https://doi. org/10.1098/rstb.2010.0324.

68. Zhang L, Yan Q, Liu J-P, Zou L-J, Liu J, Sun S, et al. Apoptosis: its functions and control in the ocular lens. Curr Mol Med. 2010;10:864-75 Bentham Science Publishers Ltd. [cited 2021 Jan 11]. Available from: https://pubmed. ncbi.nlm.nih.gov/21091420/.

69. Yan Q, Liu JP, Wan-Cheng LD. Apoptosis in lens development and pathology. Differentiation. 2006:195-211 Blackwell Publishing Ltd. [cited 2021 Jan 11]. Available from: https://pubmed.ncbi.nlm.nih.gov/16759286/.

70. Rowan S, Conley KW, Le TT, Donner AL, Maas RL, Brown NL. Notch signaling regulates growth and differentiation in the mammalian lens. Dev Biol. 2008; 321:111-22 NIH Public Access. [cited 2019 Jan 27]. Available from: http:// www.ncbi.nlm.nih.gov/pubmed/18588871.

71. Jia J, Lin M, Zhang L, York JP, Zhang P. The Notch signaling pathway controls the size of the ocular lens by directly suppressing p57Kip2 expression. Mol Cell Biol. 2007;27:7236-47 American Society for Microbiology (ASM). [cited 2019 Jan 27]. Available from: http://www.ncbi. nlm.nih.gov/pubmed/17709399.

72. Azimi M, Le TT, Brown NL. Presenilin gene function and Notch signaling feedback regulation in the developing mouse lens. Differentiation. 2018;102:
40-52 Elsevier Ltd. [cited 2021 Jan 11]. Available from: https://pubmed.ncbi. nlm.nih.gov/30059908/.

73. Rothe M, Kanwal N, Dietmann P, Seigfried FA, Hempel A, Schütz D, et al. An Epha4/Sipa1/3/Wnt pathway regulates eye development and lens maturation. Dev. 2017;144:321-33 Company of Biologists Ltd. [cited 2021 Jan 11]. Available from: https://pubmed.ncbi.nlm.nih.gov/27993984/.

74. Cvekl A, Zhang X. Signaling and gene regulatory networks in mammalian lens development. Trends Genet. 2017;33:677-702 NIH Public Access. [cited 2019 Jan 27]. Available from: http://www.ncbi.nlm.nih.gov/pubmed/2886704 8.

75. Bassnett S, Šikić H. The lens growth process. Prog Retin Eye Res. 2017;60: 181-200 NIH Public Access. [cited 2019 Jan 27]. Available from: http://www. ncbi.nlm.nih.gov/pubmed/28411123.

76. Lovicu FJ, McAvoy JW. Growth factor regulation of lens development. Dev Biol. 2005:280:1-14 Academic Press. [cited 2019 May 28]. Available from: https://www.sciencedirect.com/science/article/pii/S00121606050004 5X?via\%3Dihub.

77. Wistow GJ, Lietman T, Williams LA, Stapel SO, de Jong WW, Horwitz J, et al. Tau-crystallin/alpha-enolase: one gene encodes both an enzyme and a lens structural protein. J Cell Biol. 1988;107:2729-36 [cited 2020 Dec 7]. Available from: https://pubmed.ncbi.nlm.nih.gov/2462567/.

78. Kim RY, Lietman T, Piatigorsky J, Wistow GJ. Structure and expression of the duck a-enolase/t-crystallin-encoding gene. Gene. 1991;103:193-200 [cited 2021 Jan 11]. Available from: https://pubmed.ncbi.nlm.nih.gov/1889745/.

79. Sun M, Chen C, Hou S, Li X, Wang H, Zhou J, et al. A novel mutation of PANK4 causes autosomal dominant congenital posterior cataract. Hum Mutat. 2019;40:380-91 John Wiley and Sons Inc. [cited 2020 Dec 7]. Available from: https://pubmed.ncbi.nlm.nih.gov/30585370/.

80. Wu G, Glickstein S, Liu W, Fujita T, Li W, Yang Q, et al. The anaphasepromoting complex coordinates initiation of lens differentiation. Mol Biol Cell. 2007;18:1018-29 [cited 2021 Jan 11]. Available from: https://pubmed. ncbi.nlm.nih.gov/17215516/.

81. Furuta $Y$, Hogan BLM. BMP4 is essential for lens induction in the mouse embryo. Genes Dev. 1998;12:3764-75 Cold Spring Harbor Laboratory Press. [cited 2021 Jan 11]. Available from: https://pubmed.ncbi.nlm.nih.gov/9851 982/.

82. Shui Y-B, Arbeit JM, Johnson RS, Beebe DC. HIF-1: an age-dependent regulator of lens cell proliferation. Invest Ophthalmol Vis Sci. 2008;49:496170 NIH Public Access. [cited 2019 Feb 6]. Available from: http://www.ncbi. nlm.nih.gov/pubmed/18586877.

83. Chen KF, Lai YY, Sun HS, Tsai SJ. Transcriptional repression of human cad gene by hypoxia inducible factor-1a. Nucleic Acids Res. 2005;33:5190-8 [cited 2020 Dec 7]. Available from: https://pubmed.ncbi.nlm.nih.gov/161551 $88 /$.

84. Morote-Garcia JC, Rosenberger P, Kuhlicke J, Eltzschig HK. HIF-I-dependent repression of adenosine kinase attenuates hypoxia-induced vascular leak. Blood. 2008;111:5571-80 [cited 2020 Dec 7]. Available from: https://pubmed. ncbi.nlm.nih.gov/18309031/,

85. Zheng W, Kuhlicke J, Jäckel K, Eltzschig HK, Singh A, Sjoblöm M, et al. Hypoxia inducible factor-1 (HIF-I)-mediated repression of cystic fibrosis transmembrane conductance regulator (CFTR) in the intestinal epithelium. FASEB J. 2009;23:204-13 Wiley. [cited 2020 Dec 7]. Available from: https:// pubmed.ncbi.nlm.nih.gov/18779379/.

86. Newton IP, Kenneth NS, Appleton PL, Näthke I, Rocha S. Adenomatous polyposis coli and hypoxia-inducible factor-1a have an antagonistic connection. Mol Biol Cell. 2010;21:3630-8 [cited 2020 Dec 7]. Available from: https://pubmed.ncbi.nlm.nih.gov/20844082/.

87. Batie M, del Peso L, Rocha S. Hypoxia and chromatin: a focus on transcriptional repression mechanisms. Biomedicines. 2018:47 MDPI AG. [cited 2020 Dec 7]. Available from: www.mdpi.com/journal/biomedicines.

88. Lyu J, Joo CK. Wnt signaling enhances FGF2-triggered lens fiber cell differentiation. Development. 2004;131:1813-24 [cited 2021 Feb 15]. Available from: https://pubmed.ncbi.nlm.nih.gov/15084465/.

89. Dawes LJ, Sugiyama Y, Tanedo AS, Lovicu FJ, McAvoy JW. Wnt-Frizzled signaling is part of an FGF-induced cascade that promotes lens fiber differentiation. Investig Ophthalmol Vis Sci. 2013;54:1582-90 [cited 2021 Feb 15]. Available from: https://pubmed.ncbi.nlm.nih.gov/23385791/.

90. Hodgkinson LM, Wang L, Duncan G, Edwards DR, Michael Wormstone I. ADAM and ADAMTS gene expression in native and wound healing human lens epithelial cells. Mol Vis. 2010;16:2765-76 Emory University. [cited 2021 Feb 15]. Available from: http://www.molvis.org/molvis/v16/a297. 
91. Lachke SA, Higgins AW, Inagaki M, Saadi I, Xi Q, Long $M$, et al. The cell adhesion gene PVRL3 is associated with congenital ocular defects. Hum Genet. 2012;131:235-50 [cited 2021 Feb 15]. Available from: https://pubmed. ncbi.nlm.nih.gov/21769484/.

92. Baba Y, Watabe Y, Sagara H, Watanabe S. Sall1 plays pivotal roles for lens fiber cell differentiation in mouse. Biochem Biophys Res Commun. 2019;512: 927-33 Elsevier B.V. [cited 2021 Feb 15]. Available from: https://pubmed. ncbi.nlm.nih.gov/30929925/.

93. Majmundar AJ, Lee DSM, Skuli N, Mesquita RC, Kim MN, Yodh AG, et al. HIF modulation of wht signaling regulates skeletal myogenesis in vivo. Dev. 2015;142:2405-12 Company of Biologists Ltd. https://doi.org/10.1242/ dev.123026.

94. Chen D, Li Y, Zhou Z, Xing Y, Zhong Y, Zou X, et al. Synergistic inhibition of Wnt pathway by HIF-1a and osteoblast-specific transcription factor osterix (Osx) in osteoblasts. Samant R, editor. PLoS One. 2012;7:e52948 Public Library of Science. [cited 2020 Dec 7]. Available from: https://dx.plos.org/1 0.1371/journal.pone.0052948.

95. Mylonis I, Simos G, Paraskeva E. Hypoxia-inducible factors and the regulation of lipid metabolism. Cells. 2019;8:214 MDPI AG. [cited 2020 Nov 16]. Available from: https://pubmed.ncbi.nlm.nih.gov/30832409/.

96. Cooper SJ, Trinklein ND, Anton ED, Nguyen L, Myers RM. Comprehensive analysis of transcriptional promoter structure and function in $1 \%$ of the human genome. Genome Res. 2006;16:1-10 [cited 2020 Dec 7]. Available from: https://pubmed.ncbi.nlm.nih.gov/16344566/.

97. Whiteld TW, Wang J, Collins PJ, Partridge EC, Aldred SF, Trinklein ND, et al. Functional analysis of transcription factor binding sites in human promoters. Genome Biol. 2012;13:R50 BioMed Central. [cited 2020 Dec 7]. Available from: http://genomebiology.biomedcentral.com/articles/10.1186/gb-2 012-13-9-r50.

98. Azimi M, Brown NL. Jagged1 protein processing in the developing mammalian lens. Biol Open. 2019;8 Company of Biologists Ltd. [cited 2021 Feb 15]. Available from: http://www.ncbi.nlm.nih.gov/pubmed/30890522.

99. Garcia CM, Shui YB, Kamath M, DeVillar J, Johnson RS, Gerber HP, et al. The function of VEGF-A in lens development: formation of the hyaloid capillary network and protection against transient nuclear cataracts. Exp Eye Res. 2009:88:270-6 [cited 2021 Feb 15]. Available from: https://pubmed.ncbi.nlm. nih.gov/18782574/.

100. Martynova E, Zhao Y, Xie Q, Zheng D, Cvekl A. Transcriptomic analysis and novel insights into lens fibre cell differentiation regulated by Gata3. Open Biol. 2019;9 Royal Society Publishing. [cited 2021 Feb 15]. Available from: https://pubmed.ncbi.nlm.nih.gov/31847788/

101. Maeda A, Moriguchi T, Hamada M, Kusakabe M, Fujioka Y, Nakano T, et al. Transcription factor GATA-3 is essential for lens development. Dev Dyn. 2009;238:2280-91 [cited 2021 Feb 15]. Available from: https://pubmed.ncbi. nlm.nih.gov/19623612/.

102. Walker JL, Zhang L, Menko AS. Transition between proliferation and differentiation for lens epithelial cells is regulated by Src family kinases. Dev Dyn. 2002;224:361-72 [cited 2021 Feb 15]. Available from: https://pubmed. ncbi.nlm.nih.gov/12203728/.

103. Lyu L, Whitcomb EA, Jiang S, Chang ML, Gu Y, Duncan MK, et al. Unfoldedprotein response-associated stabilization of p27(Cdkn1b) interferes with lens fiber cell denucleation, leading to cataract. FASEB J. 2016;30:1087-95 [cited 2021 Feb 15]. Available from: https://pubmed.ncbi.nlm.nih.gov/26590164/.

104. Saravanamuthu SS, Gao CY, Zelenka PS. Notch signaling is required for lateral induction of Jagged1 during FGF-induced lens fiber differentiation. Dev Biol. 2009;332:166-76 Academic Press Inc. [cited 2021 Feb 15]. Available from: https://pubmed.ncbi.nlm.nih.gov/19481073/.

105. Chen X, Xiao W, Chen W, Liu X, Wu M, Bo Q, et al. MicroRNA-26a and -26b inhibit lens fibrosis and cataract by negatively regulating Jagged-1/Notch signaling pathway. Cell Death Differ. 2017;24(8):1431-42. https://doi.org/10.1 038/cdd.2016.152 Nature Publishing Group.

106. Reddy VN, Kasahara E, Hiraoka M, Lin LR, Ho YS. Effects of variation in superoxide dismutases (SOD) on oxidative stress and apoptosis in lens epithelium. Exp Eye Res. 2004:859-68 [cited 2021 May 4]. Available from: https://pubmed.ncbi.nlm.nih.gov/15642323/.

107. Bhuyan KC, Bhuyan DK. Superoxide dismutase of the eye Relative functions of superoxide dismutase and catalase in protecting the ocular lens from oxidative damage. BBA - Gen Subj. 1978;542:28-38 Biochim Biophys Acta. [cited 2021 Jan 11]. Available from: https://pubmed.ncbi. nlm.nih.gov/208649/.
108. Baechler BL, Bloemberg D, Quadrilatero J. Mitophagy regulates mitochondrial network signaling, oxidative stress, and apoptosis during myoblast differentiation. Autophagy. 2019;15:1606-19 Taylor and Francis Inc. [cited 2021 May 4]. Available from: https://pubmed.ncbi.nlm.nih.gov/3 0859901/.

109. Nandi SK, Nahomi RB, Harris PS, Michel CR, Fritz KS, Nagaraj RH. The absence of SIRT3 and SIRT5 promotes the acetylation of lens proteins and improves the chaperone activity of a-crystallin in mouse lenses. Exp Eye Res. 2019;182:1-9 Academic Press. [cited 2021 May 4]. Available from: https://pubmed.ncbi.nlm.nih.gov/30849386/

110. Hsu YC, Wu YT, Yu TH, Wei YH. Mitochondria in mesenchymal stem cell biology and cell therapy: from cellular differentiation to mitochondrial transfer. Semin Cell Dev Biol. 2016:119-31 Academic Press. [cited 2021 May 4]. Available from: https://pubmed.ncbi.nlm.nih.gov/26868759/.

111. Conte C, Riant E, Toutain C, Pujol F, Arnal JF, Lenfant F, et al. FGF2 translationally induced by hypoxia is involved in negative and positive feedback loops with HIF-1a. PLoS One. 2008;3 [cited 2021 May 4]. Available from: https://pubmed.ncbi.nlm.nih.gov/18728783/.

112. Bosco MC, Puppo M, Santangelo C, Anfosso L, Pfeffer U, Fardin P, et al. Hypoxia modifies the transcriptome of primary human monocytes: modulation of novel immune-related genes and identification of CCchemokine ligand 20 as a new hypoxia-inducible gene. J Immunol. 2006; 177:1941-55 The American Association of Immunologists. [cited 2021 May 4]. Available from: https://pubmed.ncbi.nlm.nih.gov/16849508/.

113. Spivakov M. Spurious transcription factor binding: Non-functional or genetically redundant? BioEssays. 2014;36:798-806 John Wiley and Sons Inc. https://doi.org/10.1002/bies.201400036.

114. Gao M, Huang Y, Wang L, Huang M, Liu F, Liao S, et al. HSF4 regulates lens fiber cell differentiation by activating $\mathrm{p} 53$ and its downstream regulators. Cell Death Dis. 2017:8:e3082 Nature Publishing Group. [cited 2019 Feb 6]. Available from: http://www.ncbi.nlm.nih.gov/pubmed/28981088.

115. Yu Y, Cui H, Chen C, Wen G, Xu J, Zheng B, et al. Hypoxia-inducible factorla directs renal regeneration induced by decellularized scaffolds. Biomaterials. 2018;165:48-55. https://doi.org/10.1016/j.biomaterials.2018.02. 045 Elsevier Ltd.

116. Chen C, Tang Q, Zhang Y, Dai M, Jiang Y, Wang H, et al. Metabolic reprogramming by HIF-1 activation enhances survivability of human adipose-derived stem cells in ischaemic microenvironments. Cell Prolif. 2017;50(5):e12363. https://doi.org/10.1111/cpr.12363.

117. Meers MP, Bryson TD, Henikoff JG, Henikoff S. Improved cut\&run chromatin profiling tools. Elife. 2019;8:e46314. eLife Sciences Publications Ltd.

118. Liu N, Hargreaves W, Zhu Q, Kurland JV, Hong J, Kim W, et al. Direct promoter repression by BCL11A controls the fetal to adult hemoglobin switch. Cell. 2018;173:430-442.e17 Cell Press. [cited 2020 Nov 17]. Available from: https://doi.org/10.1016/j.cell.2018.03.016.

119. Bolger AM, Lohse M, Usadel B. Trimmomatic: a flexible trimmer for Illumina sequence data. Bioinformatics. 2014;30:2114-20 Oxford University Press. [cited 2020 Nov 16]. Available from: http://www.usa dellab.org/cms/index.

120. Langmead B, Salzberg SL. Fast gapped-read alignment with Bowtie 2. Nat Methods. 2012;9:357-9 NIH Public Access. https://doi.org/10.1038/nmeth.1 923.

121. Li H, Handsaker B, Wysoker A, Fennell T, Ruan J, Homer N, et al. The sequence alignment/map format and SAMtools. Bioinformatics. 2009;25(16): 2078-9. Oxford Academic. [cited 2021 Jan 26]. Available from: https://aca demic.oup.com/bioinformatics/article-lookup/doi/10.1093/bioinformatics/ btp352.

122. Jurka J. Repbase update: a database and an electronic journal of repetitive elements. Trends Genet. 2000:418-20 Elsevier Ltd. [cited 2021 Jan 26]. Available from: https://pubmed.ncbi.nlm.nih.gov/10973072/.

123. Zhang Y, Liu T, Meyer CA, Eeckhoute J, Johnson DS, Bernstein BE, et al. Model-based analysis of ChIP-Seq (MACS). Genome Biol. 2008;9(9):R137. BioMed Central. [cited 2020 Nov 16]. Available from: http://genomebiology. biomedcentral.com/articles/10.1186/gb-2008-9-9-r137.

124. Feng J, Liu T, Qin B, Zhang Y, Liu XS. Identifying ChIP-seq enrichment using MACS. Nat Protoc. 2012;7:1728-40 [cited 2020 Dec 6]. Available from: https://pubmed.ncbi.nlm.nih.gov/22936215/.

125. Tanimoto K, Tsuchihara K, Kanai A, Arauchi T, Esumi H, Suzuki Y, et al. Genome-wide identification and annotation of HIF-1a binding sites in two cell lines using massively parallel sequencing. HUGO J. 2010;4:35-48 
Springer. [cited 2021 May 4]. Available from: https://thehugojournal. springeropen.com/articles/10.1007/s11568-011-9150-9.

126. Martin M. Cutadapt removes adapter sequences from high-throughput sequencing reads. EMBnet.journal. 2011;17:10 EMBnet Stichting. [cited 2020 Dec 6]. Available from: http://www-huber.embl.de/users/an.

127. Kim D, Langmead B, Salzberg SL. HISAT: a fast spliced aligner with low memory requirements. Nat Methods. 2015;12:357-60 Nature Publishing Group. [cited 2020 Dec 6]. Available from: https://pubmed.ncbi.nlm.nih. gov/25751142/.

128. Pertea M, Pertea GM, Antonescu CM, Chang TC, Mendell JT, Salzberg SL, et al. Nat Biotechnol. 2015;33:290-5 Nature Publishing Group. [cited 2020 Dec 6]. Available from: https://pubmed.ncbi.nlm.nih.gov/25690850/.

129. Robinson MD, McCarthy DJ, Smyth GK. edgeR: a bioconductor package for differential expression analysis of digital gene expression data. Bioinformatics. 2009;26:139-40 Oxford University Press. https://doi.org/10.1 093/bioinformatics/btp616.

130. Kent WJ, Sugnet CW, Furey TS, Roskin KM, Pringle TH, Zahler AM, et al. The human genome browser at UCSC. Genome Res. 2002;12:996-1006 Cold Spring Harbor Laboratory Press. [cited 2019 Feb 7]. Available from: http:// www.ncbi.nlm.nih.gov/pubmed/12045153.

131. Quinlan AR, Hall IM. BEDTools: a flexible suite of utilities for comparing genomic features. Bioinformatics. 2010;26:841-2 Oxford Academic. [cited 2020 Nov 16]. Available from: http://code.google.com/p/bedtools.

132. Yu G, Wang LG, He QY. ChIP seeker: An R/Bioconductor package for ChIP peak annotation, comparison and visualization. Bioinformatics. 2015;31: 2382-3 Oxford University Press. [cited 2020 Nov 16]. Available from: http:// www.bioconductor.org/packages/release/bioc/html/ChlPseeker.html.

133. Ramírez F, Ryan DP, Grüning B, Bhardwaj V, Kilpert F, Richter AS, et al. deepTools2: a next generation web server for deep-sequencing data analysis. Nucleic Acids Res. 2016;44:W160-5 [cited 2020 Dec 6]. Available from: https://pubmed.ncbi.nlm.nih.gov/27079975/.

134. Bailey TL, Boden M, Buske FA, Frith M, Grant CE, Clementi L, et al. MEME SUITE: tools for motif discovery and searching. Nucleic Acids Res. 2009;37: W202-8 Oxford University Press. [cited 2019 Feb 7]. Available from: https://a cademic.oup.com/nar/article-lookup/doi/10.1093/nar/gkp335.

135. Bailey TL. DREME: Motif discovery in transcription factor ChIP-seq data. Bioinformatics. 2011:27:1653-9 Oxford Academic. [cited 2020 Nov 16] Available from: https://academic.oup.com/bioinformatics/article/27/12/1 $653 / 257754$.

136. Kuleshov MV, Jones MR, Rouillard AD, Fernandez NF, Duan Q, Wang Z, et al. Enrichr: a comprehensive gene set enrichment analysis web server 2016 update. Nucleic Acids Res. 2016;44(W1):W90-7. https:/doi.org/10.1093/nar/ gkw377.

137. Xie Z, Bailey A, Kuleshov MV, Clarke DJB, Evangelista JE, Jenkins SL, et al. Gene set knowledge discovery with enrichr. Curr Protoc. 2021;1:e90 Blackwell Publishing Inc. [cited 2021 May 5]. Available from: https:// currentprotocols.onlinelibrary.wiley.com/doi/full/10.1002/cpz1.90.

138. Chen EY, Tan CM, Kou Y, Duan Q, Wang Z, Meirelles GV, et al. Enrichr: Interactive and collaborative HTML5 gene list enrichment analysis tool. BMC Bioinformatics. 2013;14 [cited 2021 May 5]. Available from: https://pubmed. ncbi.nlm.nih.gov/23586463/.

139. Liberzon A, Subramanian A, Pinchback R, Thorvaldsdóttir H, Tamayo P, Mesirov JP. Molecular signatures database (MSigDB) 3.0. Bioinformatics. 2011;27(12):1739-40.

140. Subramanian A, Tamayo P, Mootha VK, Mukherjee S, Ebert BL, Gillette MA, et al. Gene set enrichment analysis: a knowledge-based approach for interpreting genome-wide expression profiles. Proc Natl Acad Sci U S A. 2005;102:15545-50. National Academy of Sciences. https://doi.org/10.1073/ pnas.0506580102.

\section{Publisher's Note}

Springer Nature remains neutral with regard to jurisdictional claims in published maps and institutional affiliations.

Ready to submit your research? Choose BMC and benefit from:

- fast, convenient online submission

- thorough peer review by experienced researchers in your field

- rapid publication on acceptance

- support for research data, including large and complex data types

- gold Open Access which fosters wider collaboration and increased citations

- maximum visibility for your research: over $100 \mathrm{M}$ website views per year

At $\mathrm{BMC}$, research is always in progress.

Learn more biomedcentral.com/submissions 